Notre Dame Law School

NDLScholarship

1964

\title{
The Rule of Announcement and Unlawful Entry: Miller v. United States and Ker v. California
}

\author{
G. Robert Blakey Professor \\ Notre Dame Law School, g.r.blakey.1@nd.edu
}

Follow this and additional works at: https://scholarship.law.nd.edu/law_faculty_scholarship

Part of the Criminal Law Commons, Criminal Procedure Commons, and the Property Law and Real Estate Commons

\section{Recommended Citation}

G. R. Blakey Professor, The Rule of Announcement and Unlawful Entry: Miller v. United States and Ker v. California, The Rule of Announcement and Unlawful Entry: Miller v. United States and Ker v. California. Available at: https://scholarship.law.nd.edu/law_faculty_scholarship/440

This Article is brought to you for free and open access by the Publications at NDLScholarship. It has been accepted for inclusion in Journal Articles by an authorized administrator of NDLScholarship. For more information, please contactlawdr@nd.edu. 


\title{
THE RULE OF ANNOUNCEMENT AND UNLAWFUL ENTRY: MILLER V. UNITED STATES AND KER v. CALIFORNIA
}

\author{
G. ROBERT BLAKEX $\dagger$
}

[T] he sheriff (if the doors be not open) may break the party's house, either to arrest him, or to do other execution of the King's process, if otherwise he cannot enter. But before he breaks it, he ought to signify the cause of his coming, and to make request to open the doors.1

If we do not on a national scale attack organized criminals with weapons and techniques as effective as their ozm, they will destroy us.2

Mr. Justice Frankfurter, in his classic dissent in United States $v$. Rabinowitz, pointed out that "the safeguards of liberty have frequently been forged in controversies involving not very nice people." 3 Few cases decided by the Supreme Court since Rabinowitz have better illustrated that observation than Miller $v$. United States ${ }^{4}$ and Ker $v$. California. ${ }^{5}$ This Article will consider the problems posed in the administration of federal criminal justice by the "liberty forged" in these two decisions.

Until the Miller decision in 1958, the Supreme Court had never squarely considered and decided a question of announcement and unlawful entry. It is therefore appropriate to preface consideration of Miller and Ker with a review of the historical development of these concepts, the roots of which extend into early Anglo-American legal experience. ${ }^{6}$

$\uparrow$ Trial attorney, Organized Crime and Racketeering Section, United States Department of Justice. A.B. 1957, LL.B. 1960, University of Notre Dame. Member, District of Columbia, North Carolina, and Supreme Court Bars. The author wishes to express his thanks to Professor Anthony G. Amsterdam of the University of Pennsylvania Law School for his perceptive criticism of the ideas and suggestions embodied in this Article. The views expressed in this Article are solely those of the author and should not be attributed to the Department of Justice or to Professor Amsterdam.

1 Semayne's Case, 5 Co. Rep. 91a, 91b, 77 Eng. Rep. 194, 195 (K.B. 1603).

2 KeNNEDy, The ENeMry Within 265 (1960).

3339 U.S. 56, 69 (1950).

4357 U.S. 301 (1958).

5374 U.S. 23 (1963).

6 Maitland aptly observed: "Today we study the day before yesterday, in order that yesterday may not paralyze today, and today may not paralyze tomorrow." 3 Maitland, Collected Papers 439 (1911), quoted in Cardozo, The Nature of the Judiclal Process 54 (1921). 


\section{Common Law}

The common law maxim, "Every man's house is his castle," 7 severely limited the sheriff's right to make a forcible entry into a home. Although the facts in Semayne's Case, ${ }^{8}$ decided in 1603, did not involve forcible entry, ${ }^{9}$ it has long been the leading decision interpreting the maxim. In that case the court resolved six broad propositions: ${ }^{10}$

(1) Every man's house is his castle, and defense of that house may extend even to death, and it is not a felony.

(2) A sheriff may break and enter, however, to deliver seisin where a house is recovered in any real action.

(3) Yet the liberty of the house does not hold against the King, and so for felony or suspicion of felony, or to do execution of the King's process, after signifying the cause of his coming and requesting the doors to be opened, a sheriff may break and enter, if admission is refused.

(4) Where the door is open, on the other hand, a sheriff may enter to do execution on the body or the goods of a debtor, but at the suit of an individual, it is not lawful to break and enter, for the action does not concern the commonwealth.

(5) The privilege of the house is reserved, moreover, to those lawfully therein, and it does not extend to strangers or those whose goods are there to escape the processes of the law by fraud.

(6) Still, in civil cases, where entry for execution is proper, notice ought to be given so it might be known that shutting of the house is unlawful.

7 See Broom, Legal Maxims 281 (10th ed. 1929). The classic statement of the Englishman's commitment to the sacred character of his home is, of course, William Pitt's eloquent remarks in a Parliamentary debate on a proposed cider tax: "The poorest man may, in his cottage, bid defiance to all the force of the Crown. It may be frail; its roof may shake; the wind may blow through it; the storm may enter; but all his force dares not cross the threshold of the ruined tenement." Quoted in LAsSon, The History and Development of the Fourth AMinndment 49-50 (1937).

85 Co. Rep. 91a, 77 Eng. Rep. 194 (K.B. 1603).

9 Peter Semayne and George Berisford owned a house in Blackfriars in which Berisford had left some personal property. Berisford died without having paid Richard Gresham all he owed him. Gresham secured a civil writ of attachment on Berisford's property, but when the sheriff sought to serve it, Semayne denied him entry. Gresham then sued Semayne for the loss and benefit of this writ.

10 When the case first came before the Queen's Bench no decision could be reached. Chief Justice Popham and Mr. Justice Gawly were of the opinion that the sheriff had the right to break and enter. Mr. Justice Fenner and Mr. Justice Yelverton were of the contrary opinion. It was not until the first year of the reign of James I, when Mr. Justice Williams was appointed, and the case reargued, that a majority could be obtained. See Curtis v. Hubbard, 4 Hill 437, 438-39 (N.Y. 1842). 
The propositions resolved in Semayne's Case were by no means an innovation. Biblical law, for example, had prohibited a creditor from entering his debtor's house to obtain security for the debt. ${ }^{11}$ Early Anglo-Saxon law itself recognized the crime of hamsocne, the "gist of which was solely the forcible entry into a man's dwelling " 12 Passages in the earlier Year Books ${ }^{13}$ and dicta in some later cases ${ }^{14}$ reflected similar principles. Subsequent judicial treatment of civil arrest and execution, moreover, did not differ from the broad dicta of the court. ${ }^{15}$ The privilege was confined to the dwelling house, while elsewhere forcible entry was uniformily upheld. ${ }^{16}$ Only the outer door was held privileged; other doors could be broken provided initial entry was peaceful. ${ }^{17}$ Announcement was required neither before inner doors ${ }^{18}$ nor prior to entry into a nondwelling. ${ }^{19}$ "Breaking" was thought limited to forcible entry. ${ }^{20}$ However, the status of entry by trick, absent force, was not entirely clear. ${ }^{21}$

The extent to which privilege of the house extended to criminal rather than civil arrests seems never to have been considered squarely.

11 Deuteronony $24: 10$.

12 Lasson, op. cit. supra note 7, at 19. (Emphasis added.)

13 See, e.g., Y.B. Pasch. 13 Edw. 4, pl. 5. 1537).

14 See, e.g., Maleverer v. Sprinke, 1 Dyer 35b, 36b, 73 Eng. Rep. 79, 81 (K.B.

15 See, e.g., Foster v. Hill, 1 Bulstrode 146, 80 Eng. Rep. 839 (K.B. 1611); Cook's Case, Cro. Car. 537, 79 Eng. Rep. 1063 (K.B. 1640).

16 Penton v. Brown, 1 Keble 699, 83 Eng. Rep. 1193 (K.B. 1664). By analogy to the law of burglary and specifically following Semayne's Case, the court held that, to execute a civil writ, an entry without announcement into a barn not part of a dwelling house was lawful. The rule of Penton $v$. Brown is considered established beyond question in English law. See Hodder v. Williams, [1895] 2 Q.B. 663.

17 Lee v. Gansel, 1 Cowp. 1, 98 Eng. Rep. 935 (K.B. 1774). Finding that the privilege was limited to the outer door, and by analogy to the law of burglary, Lord Mansfield held that the door to a lodger's room was an inner door which could be lawfully broken to make a civil arrest when entry to the house was peaceful. It should be noted, however, that Lord Mansfield was no friend of any privilege which obstructed the collection of debts. See People v. Hubbard, 24 Wend. 368, 373-74 (N.Y. 1840).

18 Compare Ratcliffe v. Burton, 3 Bos. \& Pul. 223, 127 Eng. Rep. 123 (C.P. 1802) (required), with Hutchison v. Birch, 4 Taunt 619, 128 Eng. Rep. 473 (C.P. 1812) (not required), and Lloyd v. Sandilands, 3 Taunt. 250, 129 Eng. Rep. 379 (C.P. 1818) (same). supra.

19 Penton v. Brown, 1 Keble 699, 83 Eng. Rep. 1193 (K.B. 1664). See note 16

${ }^{20}$ See Ryan v. Shiloch, 7 Ex. 70, 155 Eng. Rep. 861 (1851) (Semayne's Case held limited to force).

21 Finding entry by fraud to serve civil process lawful, Lord Mansfield in King v. Backhouse, Lofft. 61, 98 Eng. Rep. 533 (K.B. 1772), held the householder guilty of criminal assault for putting the officer in fear of physical injury. But see Park v. Evans, Hobart 62, 80 Eng. Rep. 211 (K.B. 1615). Modern text writers have usually concluded that stratagem was lawful. See, e.g., Wilgus, Arrest Without a Warrant, 22 MICE. L. REv. 798, 806 (1924); Perkins, The Law of Arrest, 25 IowA L. REv. 201, 247 (1940). 
In addition, the right to arrest without a warrant always complicated the picture. ${ }^{22}$ It is not entirely clear that the right to arrest without a warrant automatically carried with it, in every case, the right to break doors when necessary to effect the arrest. ${ }^{23}$ The chief controversy centered on the right to arrest and break doors on a suspicion of a felony. Dictum in the early Year Books seemed to uphold the right, ${ }^{24}$ but the text writers expressed varying opinions on the issue. Lord Coke was of the extreme view that even a warrant, which might in some cases justify forcible entry, could not be issued on suspicion. He considered such procedure contrary to the Magna Carta. ${ }^{25}$ Sir Matthew Hale, on the other hand, was of the opinion that the right to arrest without a warrant carried with it the right to break doors. ${ }^{26}$ It was his view that when the officer acted virtute offici it was tantamount to a non omittus. ${ }^{27}$ The reason justifying the arrest without a warrant itself justified the breaking. William Hawkins agreed with Coke that "probable suspicion only" would not justify such an extremity. ${ }^{28}$ Sir Michael Foster likewise observed that "bare suspicion" would not justify breaking. ${ }^{29}$ Blackstone, however, recognized the right to break and enter on suspicion of felony, but limited it to the situations in which a felony had actually occurred. ${ }^{30}$

The application of the rule of announcement to criminal arrests did not receive early detailed attention by the judiciary. Most of the

22 The law of arrest without a warrant has a history and a literature of its own. Wilgus, Arrest Without a Warrant, 22 Mich. L. Rev. 541 (1924), exhaustively examines the cases.

23 It has been said that an officer's authority to break and enter a dwelling house without a warrant is limited to arrests for treason, felony, or for affray or other breach of the peace committed in his presence. See McLennon v. Richardson, 81 Mass. 74, $77(1860)$. Since the common-law restrictions on the right to arrest are usually phrased in the same terms, the rule appears to be that an officer can break doors under the common law when he is authorized to arrest. Perkins, The Law of Arrest, 25 IowA L. REv. 201, 245 n.292 (1940). See generally 76 A.L.R.2d 1432

(1961) (entry to arrest for a misdemeanor without a warrant); 5 A.L.R. 278 (1920)

(entry to arrest without search warrant).

24 See, e.g., Y.B. Pasch. 13 Edw. 4, pl. 5.

254 CoKE, INSTITUTEs $* 177-78$. None of the subsequent text writers appears to have concurred. See, e.g., Foster, CROWN LAw 321 (3d ed. 1792).

262 Hale, Pleas of the Crown *90-95, 116.

271 HALE, PleAs of THE CRown *581-83. A non omittus was a clause usually inserted in certain writs directing the sheriff not to "omit" to execute the writ because of any privilege. Black, LAW Dictronary 1203 (4th ed. 1951).

282 Hawkins, Pleas of the Crown 139 (6th ed. 1777).

29 Foster, CRown Law 321 (3d ed. 1792).

304 Blackstone, Commentaries *292. Textbook authorities still disagree. 1 BISHOP, NEW "CRIMINAL PROCEDURE \$ 196, at $144 \mathrm{n} .9$ (2d ed. 1913), terms the Hawkins' view "absurd." 1 Wharton, Criminal Procedure $\$ 51$, at $90 \mathrm{n} .1$ (10th ed. 1918), follows Hale. Russerl, Crime 440 (9th ed. 1936), has been cited for the proposition that Hale's view has been superseded. Accarino v. United States, 179 F.2d 456, 462 (D.C. Cir. 1949). Perhaps the most appropriate statement to be found in the works of the text writers is Chitty's observation that there is a "considerable degree of intricacy and confusion in the authorities which relate to this subject . . .." ChImTy, CrIMINAL IAW *51. 
text writers apparently followed Semayne's dictum without question. Sir Michael Foster, for example, broadly asserted: "In every case where doors may be broken open in order to arrest, whether in cases criminal or civil, there must be such notification, demand, and refusal, before the parties concerned proceed to that extremity." 31 It was not until 1756 in the Case of Richard Curtis, ${ }^{32}$ that the judiciary squarely faced the scope of the announcement rule in the context of a criminal case. The court unanimously upheld the right of an officer after due notice to break and enter to execute a criminal warrant for a breach of the peace. The majority also felt that "no precise form of words" would be necessary to constitute adequate notice; it was sufficient if notice was given that the party who sought to enter did not come as a trespasser. The minority thought an explicit statement explaining the warrant should have been made. ${ }^{33}$

The full scope of the application of the rule in criminal cases, however, was never judicially settled. Chief Judge Abbott, for example, in Launock v. Brozen, ${ }^{34}$ a case decided as late as 1819 , was only willing to apply the rule to situations where the offense charged was a misdemeanor. He noted that it was "not . . . necessary . . . to decide how far, in the case of a person charged with felony, it would be necessary to make a previous demand of admittance before you could justify breaking open the outer door of his house . . . ." 35

The extent to which the privilege of the house and the rule of announcement extended to the execution of search warrants at common law also seems never to have been judicially settled. At early common law the search warrant was unknown. Later, no less an authority than Lord Coke explicitly stated that its issuance, at least on suspicion, ran against the Magna Carta. ${ }^{36}$ The practice grew, however, and it received authoritative judicial approbation in 1765 in the landmark decision of Entick v. Carrington. ${ }^{37}$ Until that time the issuance and

31 Foster, Crown Law 320 (3d ed. 1792).

32 Fost. 135, 168 Eng. Rep. 67 (K.B. 1757).

33 The minority view is apparently based on the notion that notice which included only a reference to an "escape" warrant did not necessarily mean that the warrant was issued at the instance of the King and thus did not indicate forcible entry was lawful. Id. at 137, 168 Eng. Rep. at 68.

342 Barn. \& Ald. 592, 106 Eng. Rep. 482 (K.B. 1819). See also Ratcliffe v. Burton, 3 Bos. \& Pul. 223, 230, 127 Eng. Rep. 123, 127 (C.P. 1802) (judgment specifically reserved on application of the rule to criminal cases).

352 Barn. \& Ald. 592, 593, 106 Eng. Rep. 482, 483 (K.B. 1819). Mr. Justice Bayley was not as restrained in his language. He observed: "[E]ven in the execution of criminal process, you must demand admittance before you can justify breaking open the outer door." Ibid.

364 COKE, INSTitutes *177.

372 Wils. K.B. 275, 95 Eng. Rep. 807 (1765). In Boyd v. United States, 116 U.S. 616, 626 (1886), Mr. Justice Bradley termed the Entick decision "one of the permanent monuments of the British Constitution." The case involved a general 
execution of search warrants had received little attention either in the courts or from the text writers. ${ }^{38}$ Sir Matthew Hale was one of the few early writers to have devoted more than a passing reference to the search warrant. ${ }^{39}$ It was his opinion that the warrant included a non omittus of necessity, and where admittance was denied, after due demand, the executing officer could break and enter. ${ }^{40}$

\section{Early American Case Law}

The rule of Semayne's Case was widely followed in early American decisions. Civil arrest, it was held, could not be made by forcible entry into a dwelling house. The leading American case is usually thought to be Oystead $v$. Shed, ${ }^{41}$ decided by the Massachusetts Supreme Court in 1816. Likewise, a civil execution could not be lawfully made by breaking and entering. ${ }^{42}$ Here Haggerty $v$. Wilber, ${ }^{43}$ which was decided in the Supreme Court of New York in 1819, is the case most often cited. Consistently with Semayne's Case, it was held that the privilege of the house did not obtain when the forcible entry was made to seize specific goods ${ }^{44}$ or possession of the house itself. ${ }^{45}$

Most of the traditional common-law qualifications of the privilege were also widely adopted. The distinction between the inner door and

warrant issued by Lord Halifax, the Secretary of State, to search the house of John Wilkes for alleged seditious libels. Lord Camden held the search illegal, yet observed that a warrant could be issued for stolen goods. 2 Wils. K.B. at 291-92, 95 Eng. Rep. at 818.

38 The legislative history of English search warrant practice is summarized in LASSON, op. cit. supra note 7 , at 23-50.

392 Hale, Pleas of the Crown *149-51; Chitry, Criminal Law *64-67. Chitty agreed that "upon demand, not opened" breaking in the execution of a search warrant was proper. Id. at *66.

402 Hale, Pleas of the Crown *150. Hale expressed two views on the matter. Early in his treatise he denied the right, asserting that such entry must be per ostia apentia. Id. at $* 116-17$. He is, however, usually thought to have held finally the later view. See Androscoggin R.R. v. Richards, 41 Me. 233, 238 (1856); Bell v. Clapp, 10 Johns. R. 263, 265 (N.Y. Sup. Ct. 1813) ; Chipman v. Bates, 15 Vt. 51, 60 (1843). Hale's view usually represented the current law or recommended a better practice which later "hardened into law." LASson, op. cit. supra note 7, at 35.

4113 Mass. 520 (1816). The decision actually turned on a procedural point concerning the manner in which the action was pleaded. Yet, underlying the decision was a substantive argument about the rights of a permanent lodger in a dwelling house to be free from forcible civil arrest. The Supreme Court of New York had earlier decided that a civil arrest could forcibly be made where only an inner door was involved. Williams v. Spencer, 5 Johns. R. 352 (N.Y. Sup. Ct. 1810) (per curiam). The Oystead decision, however, is the case usually cited for the broad proposition.

42 Snydacker v. Brosse, 51 Ill. 357 (1869); Ilsley v. Nichols, 29 Mass. (12 Pick.) 270 (1832) ; Bailey v. Wright, 39 Mich. 96 (1878).

4316 Johns. R. 287 (N.Y. Sup. Ct. 1819) (forcible entry permissible under civil writ to attach goods in a store). Actually, the first American decision to deal with forcible entry under a writ of attachment was State v. Thacham, 1 Bay 358 (S.C. 1794) (entry could not be made at night to attach a slave).

44 Keith v. Johnson, $31 \mathrm{Ky}$. 604 (1833). But cf. State ex rel. McPherson v. Beckner, 132 Ind. 371, 31 N.E. 950 (1892).

45 Howe v. Butterfield, 58 Mass. (4 Cush.) 302 (1849). 
the outer door, although criticized, ${ }^{46}$ was followed. ${ }^{47}$ Forcible entry was allowed into nondwellings such as stores ${ }^{48}$ and warehouses. ${ }^{49}$ Breaking was still understood in a physical sense, and acts such as lifting a latch ${ }^{50}$ or gaining entrance through a broken window ${ }^{51}$ were held to constitute an unlawful breaking within the rule. It was asserted, moreover, in Curtis v. Hubbard" 52 that what "would be breaking of the outer door in burglary, is equally breaking by the sheriff."

Where forcible entry into a dwelling or a building within the curtilage was lawful, the requirement of notice was usually thought to obtain, ${ }^{53}$ but it was not mechanically applied. Notice was not required when it would be useless, ${ }^{54}$ when it would constitute a senseless ceremony, ${ }^{55}$ when no one was evidently present to hear it, ${ }^{86}$ or when the officer was invited into the house. ${ }^{57}$ Notice was apparently not required prior to entry into a nondwelling not within the curtilage. ${ }^{58}$

The Connecticut case of Read $v$. Case ${ }^{59}$ occupies a middle position between the usual criminal or civil case. Finding that a bail, or a sheriff acting in his behalf, may, after due demand, break and enter to take a principal, the court carved an exception out of the general requirement of announcement and held that the possibility of imminent danger to human life obviated the necessity of notice. It seems that Read, the principal, had asserted he would defend himself with a gun if necessary. The court concluded that any other holding would be a "palpable perversion" of an otherwise sound rule. Read v. Case is the

46 Fitch v. Loveland, Kir. 380 (Conn. 1788).

47 E.g., Stedman v. Crane, 52 Mass. (11 Met.) 295 (1846) ; Hubbard v. Mace, 17 Johns. R. 127 (N.Y. Sup. Ct. 1819); William v. Spencer, 5 Johns. R. 352 (N.Y. Sup. Ct. 1810).

48 Haggerty v. Wilbur, 16 Johns. R. 287 (N.Y. Sup. Ct. 1819). In Stearns v. Vincent, 50 Mich. 209, 15 N.W. 86 (1883), a case involving a store-dwelling, although the court recognized the relevancy of cases involving burglary, it held that what might be a dwelling for burglary would not necessarily be a dwelling entitled to the protection of the home.

49 Burton v. Wilkinson, 18 Vt. 186 (1846).

50 Walker v. Fox, $32 \mathrm{Ky} .404$ (1834).

51 Welsh v. Wilson, 34 Minn. 92, 24 N.W. 327 (1885).

521 Hill 336, 338 (N.Y. Sup. Ct. 1841), aff'd, 4 Hill 437 (N.Y. 1842) (door merely opened without other force).

53 Burton v. Wilkinson, 18 Vt. 186, 189 (1846).

64 Howe v. Butterfield, 58 Mass. (4 Cush.) 302 (1849) (dictum) (knowledge that entry was to be forcibly resisted).

55 Allen v. Martin, 10 Wend. 300 (N.Y. Sup. Ct. 1833) (reentry made to recapture escaped prisoner).

56 Howe v. Butterfield, 58 Mass. (4 Cush.) 302 (1849).

57 Hitchcock v. Holmes, 43 Conn. 528 (1876) (overtones of stratagem, yet entry still upheld).

58 See Haggerty v. Wilbur, 16 Johns. R. 287 (N.Y. Sup. Ct. 1819) ; Burton v. Wilkinson, $18 \mathrm{Vt}$ 186, 189 (1846) (dictum).

594 Conn. 166 (1822). 
leading American decision articulating an exception to the general requirement of announcement based on the possibility of peril.

American decisions also purported to follow the rule of Semayne's Case in the execution of criminal arrest warrants. Decided in 1783, Kelsy v. Wright ${ }^{60}$ is the first American case squarely to face the problem of forcible entry in the context of a criminal warrant. The case held that such an entry to execute a warrant for treason was lawful. No question of due notice was presented to the court, however, since the officers did not in fact break in until admission was refused after an announcement of purpose and a demand for entry. A similar result was reached six years later in a case involving a warrant for lewd behavior. ${ }^{61}$ Explicitly purporting to follow Semayne's Case, the Supreme Court of Massachusetts in Commonwealth v. Reynolds broadly asserted:

The doctrine that a man's house is his castle, which cannot be invaded in the service of process, was always subject to the exception that the liberty or privilege of the house did not exist against the King. It had no application, therefore, to the criminal process. ${ }^{62}$

The rule of announcement as such received little direct attention in the early decisions involving arrest on a warrant. No case actually held illegal an arrest on the grounds of inadequate notice. On the contrary, the Court of Appeals of Kentucky observed in Hawkins $v$. Commonwealth" that no notice was required in criminal cases: "Such disclosure . . . would in many cases defeat the very object in view, by giving the offender notice of his danger, and an opportunity of effecting his escape." "64 The usual situation, however, is illustrated by

601 Root 83 (Conn. 1783). The case also stands for the proposition that the entry is lawful although the person sought is not found; it is sufficient that the sheriff had good cause to suspect he was within the house. Accord, Hawkins v. Commonwealth, $53 \mathrm{Ky} .395$ (1854); Barnard v. Bartlett, 64 Mass. (10 Cush.) 501 (1852) (notice required).

61 State v. Shaw, 1 Root 134 (Conn. 1789).

62120 Mass. 190, 196 (1876) (misdemeanor warrant); accord, United States v. Faw, 25 Fed. Cas. 1053 (No. 15079) (C.C.D.C. 1808). The principal case also stands for the proposition that the party need not be found to justify the breaking of another person's house if the officer has reasonable grounds for suspecting that the party is within the house. Hale apparently was of a contrary view. 2 HALE, PLEAS OF THE CROWN *116; accord, Hawkins v. Commonwealth, $53 \mathrm{Ky} .395$ (1854). However, the Supreme Court of Massachusetts had noted earlier, in Commonwealth v. Irwin, 83 Mass. 587, 589-90 (1861), that Hale's view should be limited to cases in which there is no reasonable suspicion that the party is within the house. The principal case merely follows this dictum. It also holds that no notice of whom the warrant is for need be given unless requested.

63 Hawkins v. Commonwealth, 53 Ky. 395 (1854).

64 Id. at 397. MURFREE, SHERIFFs $\$ 1163$ (1884), moreover, terms the Hazokins rule better in felony cases. 
Commonwealth $v$. Reynolds, ${ }^{65}$ in which announcement of identity and purpose was made prior to forcible entry. The court observed:

Even in case of a misdemeanor, while it has been held in some cases that, before breaking open the outer door, the officer should demand admission, it is fully recognized in all the cases, that, after such demand and its refusal, the officer may lawfully enter by force . . . . ${ }^{66}$

Only a few early cases considered the right to break and enter to make an arrest without a warrant. The Massachusetts Supreme Court in McLennon v. Richardson, ${ }^{67}$ however, did at least offer broad dictum on the question: "The authority of a constable to break open doors and arrest without a warrant is confined to cases where treason or felony has been committed, or there is an affray or a breach of the peace in his presence." Other early cases generally supported this observation. Forcible entry ${ }^{68}$ to protect a threatened wife, ${ }^{69}$ to recapture an escaped prisoner, ${ }^{70}$ or to arrest for an actual breach of the peace was upheld. ${ }^{71}$ A forcible entry solely to search for crime, however, was condemned. ${ }^{72}$

The question of forcible entry pursuant to a search warrant first met judicial attention in America in Bell $v$. Clapp, ${ }^{73}$ which was decided by the New York Supreme Court in 1813. Following Lord Camden's opinion in Entick $v$. Carrington, ${ }^{74}$ the court held the search warrant valid and affirmed the right of the executing officer, upon due demand, to break and enter. The court commented that such warrants "would be of little or no efficacy without this power attached to them." 75

65120 Mass. 190 (1876). See also Barnard v. Bartlett, 64 Mass. 501 (1852); Jacobs v. Measures, 79 Mass. 74 (1859); State v. Smith, 1 N.H. 346 (1818).

66120 Mass. at 196.

6781 Mass. 74,77 (1860). The case actually held unlawful an entry to arrest for a mere liquor violation not amounting to an actual disturbance. The court observed that the situation did not require "the immediate intervention of legal authority" because of the "grave nature of the offense" or because an actual disturbance of "the public peace" was occurring. Accord, Delafoile v. State, 54 N.J.L. 381, 24 Atl. 557 (Ct. Err. \& App. 1892). Justice Knapp in the Delafoile decision adds the situation where "there is a well founded belief of crime, and the officer goes in pursuit of the criminal ...."Id. at 384,24 Atl. at 558. It is not clear whether "crime" means only felony and pursuit must be "fresh." See Restatement, Torts \$206, comment $f$ (N.J. Annot. 1940).

68 The Massachusetts Supreme Court also affirmed the right of an officer to enter through an open door, without warrant or permission, to arrest for a breach of the peace. Ford v. Breen, 173 Mass. 52, 53 N.E. 136 (1899).

60 State v. Stouderman, 57 La. Ann. 286 (1851).

70 Cahill v. People, 106 I1l. 621 (1883).

71 State v. Lafferty, 5 Del. (5 Harr.) 491 (1854); accord, Commonwealth v. Tobin, 108 Mass. 426 (1871).

72 Bailey v. Ragatz, 50 Wis. 554 (1880) (prostitution).

7310 Johns. R. 263 (N.Y. Sup. Ct. 1813).

7419 How. St. Tr. 1030, 95 Eng. Rep. 807 (K.B. 1765).

75 Bell v. Clapp, 10 Johns. R. 263, 265 (N.Y. Sup. Ct. 1813). 
Once again, however, the issue of announcement was not before the court, since the officer had made an announcement. The Supreme Court of Massachusetts in 1841 reached a like result in Commonwealth $v$. Dana, ${ }^{76}$ and other early decisions expressed similar views. ${ }^{77}$

One early case considered the question of forcible entry in the context of the execution of a search warrant without an announcement, but that case did not involve a dwelling. The Supreme Court of Maine in Androscoggin R.R. v. Richards, ${ }^{78}$ upheld such an entry into a train depot to execute a search warrant for liquor. The court offered this cryptic observation: "There was no person in the depot, or around it, at the time of its entry by the officer, from whom he could have demanded admission." "79 Although the courts usually dealt with the question of announcement only in dicta, the formulation of the rule was not inflexible. For example, the Supreme Court of Massachusetts in Jacobs v. Measures ${ }^{80}$ spoke of "breaking the outer door of a dwelling house, after demanding admittance and being refused," while the same court in Barnard $v$. Bartlett ${ }^{81}$ had earlier seemed to require only "notification of purpose" prior to such breaking.

\section{Modern American Statutes and Case Law}

During the last half century, a number of states and the federal government have enacted statutes dealing with forcible entry. ${ }^{82}$ Thirtythree states have statutes authorizing an officer to break and enter a dwelling house or other building to make an arrest. Only nine expressly qualify that power when the officer is acting without a warrant, while twenty grant it across the board. Usually, if qualified, the power is limited to felony cases. Twenty-nine states and the federal government have statutes authorizing forcible entry in the execution of search warrants. Almost invariably the statutes condition the right to break and enter upon due notice. ${ }^{83}$ None attempts to codify any common-law exceptions.

7643 Mass. 329 (1841). This decision is also one of the first American cases to reject the plea that illegally seized evidence be excluded in a criminal trial.

77 Chipman v. Bates, 15 Vt. 51 (1843) (no forcible entry); Beaty v. Perkins, 6 Wend. 382 (N.Y. 1831) (same).

$7841 \mathrm{Me} .233$ (1856).

$79 \mathrm{Id}$. at 238.

8079 Mass. 74, 75 (1859).

8164 Mass. 501, 503 (1852).

82 See Appendix A for a detailed analysis of the various statutes.

83 Only the Georgia statute does not expressly so condition the right. The provision, however, is "simply an attempted codification of the common law . - .." Hollinshed v. Shadrick, 95 Ga. App. 88, 90, 97 S.E.2d 165, 167 (1957). It probably would be interpreted to include such a restriction. See Groves v. State, 175 Ga. 37, 41,164 S.E. 822,824 (1932). 
The last half century has also seen cases involving forcible entry arise in a number of states ${ }^{84}$ and in the federal courts. ${ }^{85}$ The range of judicial treatment of the problem is best illustrated by decisions from two jurisdictions: the District of Columbia and California.

84 Alabama: Gray v. Williams, 230 Ala. 14, 160 So. 715 (1934) (need not mention arrest warrant unless asked); Jones v. State, 4 Ala. App. 159, 58 So. 1011 (1912) (entry with search warrant without notice not illegal where no one present). Arizona: Argetakis v. State, 24 Ariz. 599, 212 Pac. 372 (1923) (entry to arrest for felony without notice or warrant upheld) ; Adair v. Williams, 24 Ariz. 422, 210 Pac. 853 (1922) (entry to arrest for misdemeanor without notice or warrant held illegal). Florida: Johnson v. State, 157 Fla. 685,27 So. 276 , cert. denied, 329 U.S. 799 (1946) (forcible entry issue resolved by finding entry peaceful). Georgia: Groves v. State, $175 \mathrm{Ga}$.37, 164 S.E. 822 (1932) (entry with arrest warrant and notice upheld). Indiana: Schreiber v. State, 201 Ind. 27, 164 N.E. 258 (1928) (entry to execute search warrant after announcement of only identity upheld); Jones v. State, 89 Ind. App. 564, 166 N.E. 158 (1929) (execution of search warrant without notice to prevent destruction of evidence upheld). Kentucky: Stader v. Commonwealth, $302 \mathrm{Ky}$. 330, 194 S.W.2d 368 (1946) (entry to execute search warrant without notice upheld); Weaver v. McGovern, $122 \mathrm{Ky} .1$, 90 S.W. 984 (1906) (disturbance held to validate entry to arrest without warrant). Maryland: Frankel v. State, 178 Md. 553, 16 A.2d 93 (1940) (notice of identity in execution of search warrant held sufficient); Goodman v. State, 178 Md. 1, 11 A.2d 635 (1940) (dictum) (demand in execution of search warrant need only be made where someone is present). Massachusetts: Commonwealth v. Phelps, 209 Mass. 396, 95 N.E. 868 (1911) (entry to arrest for suspicion of felony without warrant upheld). Mississippi: Love v. State, 142 Miss. 602, 107 So. 667 (1926) (entry to arrest for a felony without warrant and without notice upheld). Michigan: People v. Woodward, 220 Mich. 511, 190 N.W. 721 (1922) (entry to stop loud noise without warrant upheld). New York: Phelps v. McAdoo, 94 N.Y.S. 265 (Sup. Ct. 1905) (dictum) (execution of search warrant must be with notice). Oklahoma: Kelso v. State, 97 Okla. Crim. 215, 260 P.2d 864 (1953) (entry with search warrant without notice upheld where inmate knew authority and purpose); Thigpen v. State, 51 Okla. Crim. 28, 299 Pac. 230 (1931) (entry with search warrant without notice upheld where no one present); accord, Pennington v. State, 302 P.2d 170 (Okla. 1956). Oregon: State v. Duffy, 135 Ore. 290, 295 Pac. 953 (1931) (entry without notice or warrant to arrest for crime committed in presence upheld where officer recognized inmate); State v. Yarde, 121 Ore. 297, 254 Pac. 798 (1927) (dictum) (right to enter for felony without warrant upheld). Tennessee: Collins v. State, 184 Tenn. 356, 199 S.W.2d 96 (1947) (execution of search warrant without notice upheld where no one was present; dictum, that invalidity not grounds for suppression); McCaslin v. McCord, 116 Tenn. 690, 94 S.W. 79 (1906) (private person without warrant cannot enter to recapture prisoner). Texas: Condra v. Anderson, 254 S.W.2d 528 (Tex. Civ. App. 1953) (entry without notice to execute search warrant not illegal); Booker v. State, 130 Tex. Crim. 460, 94 S.W.2d 75 (1936) (same); McGee v. State, 121 Tex. Crim. 188, 51 S.W.2d 714 (1932) (search after entry to execute search warrant without notice upheld); Elms v. State, 114 Tex. Crim. 642, 26 S.W.2d 211 (1930) (entry without notice to execute search warrant upheld when no one was present) ; Goodspeed v. State, 114 Tex. Crim. 334, 25 S.W.2d 858 (1929) (dictum) (entry should always be made only on usual formalities); Justice v. State, 112 Tex. Crim. 586, 18 S.W.2d 657 (1929) (dictum) (entry without notice to execute search warrant not grounds for suppressing evidence); Kelley v. State, 80 Tex. Crim. 257, 190 S.W. 169 (1916) (entry by trick to arrest for felony recognized if danger possible). Utah: State v. Williams, 49 Utah 320, 163 Pac. 1104 (1917) (entry to arrest for felony without a warrant and without notice of purpose held valid where purpose understood). Wisconsin: Hiller v. State, 190 Wis. 369,280 N.W. 260 (1926) (entry with search warrant but without notice upheld where facts indicated admission refused), overruled on other gronnds, Glodowski v. State, 196 Wis. 265, 220 N.W. 227 (1928); Lehrer v. State, 183 Wis. 339, 197 N.W. 729 (1924) (valid execution of search warrant).

85 To arrest under a warrant: Townsend v. United States, 271 F.2d 445 (4th Cir. 1959) (entry by postal inspector with valid search warrant upheld); United States v. Petti, 168 F.2d 221 (2d Cir. 1948), vacated, 336 U.S. 916 (1949) (entry by landlord with arrest warrant upheld); Lane v. United States, 148 F.2d 816 ( 5 th Cir. 1945), cert. denied, 326 U.S. 720 (1945) (seizure of still after entry with arrest warrant upheld although party not found; state law not discussed); Paper v. United 


\section{A. The District of Columbia}

Cases presenting forcible entry problems arose in the District of Columbia as early as $1808,{ }^{86}$ but the question did not receive extended judicial attention until 1949 when Accarino v. United States ${ }^{87}$ was decided. Accarino was forcibly arrested in his home without a warrant, and evidence of a gambling operation was seized at that time. The Court of Appeals for the District of Columbia ordered the evidence suppressed. Judge Prettyman's opinion found Accarino's arrest illegal on two grounds: no exceptional circumstances which would have authorized a forcible arrest without a warrant in his home were shown; and prior to the forcible entry the arresting officers did not announce their purpose. The opinion was based on a series of Supreme Court decisions, chiefly $M c D o n a l d v$. United States, ${ }^{88}$ and an extensive review of common-law cases and materials. The rationale which Judge Prettyman derived from the Supreme Court's decisions, how-

States, 53 F.2d 184 (4th Cir. 1931) (same); United States v. Pappadementro, 6 Alaska 769 (1922) (entry with misdemeanor warrant without notice or reasonable cause to think party was within house held unconstitutional).

To arrest zeithout a warrant: Martin v. United States, 183 F.2d 436 (4th Cir. 1950), cert. denied, 340 U.S. 904 (1950) (entry to arrest without warrant or notice held constitutional); Taylor v. United States, 55 F.2d 58 (4th Cir. 1932) (entry upheld under power to arrest without warrant for crime in presence); United States v. Colebrook, 52 F.2d 307 (S.D. Tex. 1931) (entry to arrest without warrant held illegal under state law); Rouda v. United States, 10 F.2d 916 (2d Cir. 1926) (entry to arrest without warrant for crime in presence upheld); McBride v. United States, 284 Fed. 416 (5th Cir. 1922), cert. denied, 261 U.S. 614 (1922) (same; state law discussed).

- To search under a warrant: Appell v. United States, 29 F.2d 279 (5th Cir. 1928) (entry under invalid search warrant without notice upheld under power to arrest without warrant; state law not discussed); Lee Kwong Nom v. United States, 20 F.2d 470 (2d Cir. 1927) (search after entry into public place to execute search warrant upheld under power to search incident to arrest without warrant); Mattus v. United States, 11 F.2d 503 (9th Cir. 1926) (entry under invalid search warrant with notice of authority upheld under power to arrest without warrant; state law not discussed); United States v. Chin On, 297 Fed. 531 (D. Mass. 1924) (entry with invalid search warrant upheld under power to arrest without warrant; state law discussed); United States v. Freeman, 144 F. Supp. 669 (D.D.C. 1956) (execution of search warrant with only notice of authority upheld under \$ 3109); United States v. Bowman, 137 F. Supp. 385 (D.D.C. 1956) (entry through unlocked doors without notice to execute search warrant upheld under $\$ 3109$; Barrientes v. United States, 235 F.2d 116 (5th Cir. 1956), cert. denied, 352 U.S. 879 (1956) (dictum) (failure to give notice in execution of search warrant not grounds for suppression under \$ 3109); United States v. Freeman, supra (dictum) (same).

To search without a warrant: Here entry cases are usually resolved without directly considering the issue of force. Such cases come under the general prohibition of search without a warrant. See Taylor v. United States, 286 U.S. 1 (1931).

86 United States v. Faw, 25 Fed. Cas. 1053 (No. 15079) (C.C.D.C. 1808) (right to break doors to execute arrest warrant upheld). Wells v. Hubbard, 29 Fed. Cas. 657 (No. 17397) (C.C.D.C. 1822) (right similar to that upheld in Fawe denied in execution of civil writ). Neither decision mentioned the rule of announcement. Compare Gibson v. United States, 149 F.2d 381 (D.C. Cir. 1945), with Beard v. United States, 82 F.2d 837 (D.C. Cir. 1936).

87179 F.2d 456 (D.C. Cir. 1949).

88335 U.S. 451 (1948) (entry to search and arrest without search or arrest warrant held illegal). 
ever, was almost immediately overturned. ${ }^{89}$ What Judge Prettyman did in Accarino was to confuse the warrantless arrest with the warrantless search. He was therefore compelled to create an exception to what he apparently thought was, or ought to be, the general rule-that searches and arrests must always be on a warrant. His logic could have forced him to hold that the warrantless arrest is always illegal absent compelling circumstances. He limited his holding, however, to

89 Rabinowitz v. United States, 339 U.S. 56, 67 (1950). Traditionally, if not always rationally, Anglo-American law has drawn a sharp distinction between arrest and search. See generally Barrett, Personal Rights, Property Rights, and the Fourth Amendment, in 1960 Supreme Courr Review 46 (Kurland ed.). The right to arrest without a warrant was recognized prior to the development of the warrant procedures and was never supplanted by them. Wilgus, Arrest Without a Warrant (pts. 1-2), 22 MicE. L. REv. 541, 548-50, 673, 685-89 (1924). Historically, arrest warrant procedures arose solely out of a desire to protect the arresting officer from tort liability. Stephens, History of the CrIMINaI Law of ENGLand 190-93 (1883). The right to search without a warrant, however, received no such independent favorable development. See generally LASSON, THE Hrstory AND DevelopMent of THE FourTh AMENDMENT 23-50 (1937).

This independent historical development has been reflected, although not always with clarity or consistency, in the interpretation of the fourth amendment. The warrantless search, for example, is usually unlawful. Taylor v. United States, 286 U.S. 1 (1932). Only the most limited exceptions to this rule have been recognized the automobile being the most notable illustration. See Carroll v. United States, 267 U.S. 132 (1925). The amendment, of course, applies to arrests as well as searches. Albrecht v. United States, 273 U.S. 15 (1927). Yet Trupiano v. United States, 334 U.S. 699, 705 (1948), the high water mark of the independent magistrate rationale, explicitly rejected a rule which would have always required a warrant prior to making an arrest.

Difficulties of interpretation and theory, on the other hand, arise when a search is made incident to an arrest or an arrest is made as a pretext to search. The power to search incident to an arrest is of ancient origin; it "goes back beyond doubt to the days of the hue and cry." People v. Chiagles, 237 N.Y. 193, 196, 142 N.E. 583, 584 (1923) (Cardozo, J.). As such, it is "not to be doubted." Agnello v. United States, 269 U.S. 20, 30 (1925). Using regrettably broad language, however, the Supreme Court in McDonald v. United States, 335 U.S. 451 (1948), Trupiano v. United States, 334 U.S. 699 (1948), and Johnson v. United States, 333 U.S. 10 (1948), developed the rule that a warrant must be obtained whenever practicable prior to making a search. So enthroned, the independent magistrate rule had a short life. Two years later in Rabinowitz v. United States, 339 U.S. 56 (1950), the court specifically overruled Trupiano and substituted for the rule of the magistrate the concept of "reasonableness." See generally Note, 28 U. CHI. L. REV. 664, 678-86 (1961).

Despite the doctrinal differences expressed in this series of cases, it is important to recognize that the underlying controversy actually centered not on the right to search incident to an arrest, but on its justification and proper scope. To the degree that Rabinowitz returned to the older rule of Harris v. United States, 331 U.S. 145 (1947) (four room apartment thoroughly searched), that scope is today highly permissive. How long it will remain so is open to question. See, e.g., Abel v. United States, 362 U.S. 217, 237 (1960). It is probably only a matter of time until Mr. Justice Frankfurter's masterful dissent in Rabinoweritz becomes law. In fact, Mr. Justice Frankfurter concurring in Chapman v. United States, 365 U.S. 610, 618 (1961), expressed the view that the Court had by its decision quietly buried Rabinozvitz. It is also interesting and confusing to note that the Court still continues to speak of search incident to arrest as an "exception." See, e.g., Rios v. United States, 364 U.S. 253, 261 (1960); Jones v. United States, 357 U.S. 493, 499 (1958); United States v. Jeffers, 342 U.S. 48, 51 (1951).

The pretext arrest has provoked no similar conflict in the Court. An arrest made to search is invariably thought illegal. See, e.g., United States v. Lefkowitz, 285 U.S. 452, 467 (1932) (dictum). The chief controversy in this area has not centered on theoretical differences but on varying interpretations of the facts. See, e.g., Jones v. United States, supra. 
requiring such circumstances only in the situation in which the arrest is made in the home. ${ }^{90}$ Judge Prettyman concluded that the common law supported his view that exceptional circumstances are required before a warrantless arrest can be made in a house. However, the judge's finding, if not in error, was at least strained. Most early common-law authorities were primarily concerned with civil-law aspects of forcible entry in the context of civil arrest or execution. ${ }^{91}$ Proper announcement arose only incidentally. Forcible entry and announcement in the context of the administration of criminal justice received little or no treatment. Moreover, Judge Prettyman explicitly rejected the rule of the majority of American jurisdictions which either by statute or decision follow Commonwealth v. Phelps, ${ }^{92}$ that forcible entry to arrest without a warrant is legal. Accarino is also the first judicial decision in Anglo-American law invalidating an arrest on the independent ground that an announcement of purpose was not made prior to forcible entry. ${ }^{93}$ Judge Prettyman observed that the common-law authorities expressed no disagreement on this point. A more accurate description of these authorities is that they never really considered the problem. ${ }^{94}$

Despite the questionable character of Accarino, ${ }^{95}$ for the most part it has been followed on the question of announcement and even

80 The Supreme Court has never squarely dealt with this problem, although Jones v. United States, 357 U.S. 493 (1958), did present the question. Mr. Justice Harlan resolved the issue, however, by finding that the entry was made to search rather than to arrest. He observed that a nighttime forcible entry to arrest without a warrant when there was ample time to obtain one presented "a grave constitutional question." Id. at 499. Justices Clark and Burton in dissent would have squarely met the problem; but they did not find the question so grave. Id. at 503 . For the English rule on this question, see Samuel v. Payne, 1 Doug. 359, 99 Eng. Rep. 230 (K.B. 1780) (arrest without warrant in home upheld when arresting officer had reason to believe felony was being committed).

91 See text accompanying notes 7-40 sipra.

92209 Mass. 396, 95 N.E. 868 (1911).

93 The officers only announced, "Police." Accarino v. United States, 179 F.2d 456, 457 (D.C. Cir. 1949).

$94 \mathrm{His}$ only support on this point is Chitty, who observed that "where the law is silent, and express principles do not apply, this extreme violence is illegal." CHITTY, CRIMINAL LAW *52. It should also be pointed out in Judge Prettyman's favor that Accarino was decided prior to the Rabinowitz rejection of the rationale of McDonald. The arrest to search factor present in Accarino may also have moved him to an otherwise unsound decision.

95 Smith v. United States, 254 F.2d 751 (D.C. Cir.), cert. denied, 357 U.S. 937 (1958), and Washington v. United States, 263 F.2d 742 (D.C. Cir.), cert. denied, 359 U.S. 1002 (1959), are difficult to reconcile with the exceptional circumstances holding of Accarino. A close reading of Smith indicates that Judge Bastian only gave lip service to Accarino when he permitted the introduction of oral statements made after an entry without a warrant or exceptional circumstances. The opinion is also unfaithful to Neuslein v. United States, 115 F.2d 690 (D.C. Cir, 1940), on the oral statements point. In that case, then-Judge Vinson held that oral statements heard by officers after an illegal entry in violation of the Fourth Amendment were inadmissible even if voluntarily made. See Jackson v. United States, 302 F.2d 194 (D.C. Cir. 1962), which appears to have finally eliminated the exceptional circumstances rule. 
extended beyond its immediate facts. The court in Gatewood $v$. United States ${ }^{96}$ applied the Accarino rule of notice, at least alternatively, to a forcible entry made without announcement to execute a bench warrant. The Government attempted to distinguish the facts of Accarino on a warrant-no-warrant basis. The court rejected the distinction terming the difference "immaterial." 97

For a number of years the execution of search warrants in the District of Columbia has been governed by 18 U.S.C. $\S 3109$, which is a federal statute of general application. ${ }^{98}$ It grants the right to break and enter to execute a search warrant when admission is refused after due notice. Prior to 1958, only a few reported cases considering the meaning of the statute arose. Mattus $v$. United States ${ }^{99}$ had, however, held that the precodification form of section 3109 did not invalidate an entry made both to arrest on probable cause without a warrant and to serve an invalid search warrant. The officers had forced an entrance after receiving no response to an announcement of identity only. Under section 3109 , as it was later codified, Judge Holtzoff, also upheld a similar entry, ${ }^{100}$ commenting: "[T]he announcement that the police were seeking to enter would give notice to a reasonable person that the purpose of seeking the entry is either to make an arrest or to make a search and that it was not just a social visit." Chief Judge Laws in United States v. Borman ${ }^{101}$ likewise upheld an entry, under section 3109 , although no announcement was made, on the ground that no "breaking" was involved. He limited the statute to the forcible entry situation. ${ }^{102}$

Prior to 1958, motions to suppress under section 3109 had also reached the appellate level. Both the Court of Appeals for the Fifth Circuit and the Court of Appeals for the District of Columbia Circuit had considered the effect of a possible violation of the statute. The Fifth Circuit observed in Barrientes v. United States" ${ }^{103}$ that, "while

96209 F.2d 789 (D.C. Cir. 1953) (ruse to get door open with force).

97 Id. at 791 . The court also held that even if the existence of a warrant made a difference no warrant was outstanding.

98 The substance of 18 U.S.C. $\$ 3109$ (1958) was originally in the Espionage Act of 1917, ch. 30, tit. XI, § 8, 40 Stat. 229. It "was based upon the New York law on this subject." H.R. REP. No. 69, 65th Cong., 1st Sess. 20; 55 CoNG. REc. 3305, 3307 (1917). Interestingly enough, the New York cases prior to 1958 had never considered the application of their statutory announcement rule. The best that can be said for the New York practice generally is that it was supposed to reflect the common law. See People v. Kemper, 208 N.Y. 16, 20-23, 101 N.E. 794, 796-97 (1913). 9911 F.2d 503 (9th Cir. 1926).

100 United States v. Freeman, 144 F. Supp. 669, 670 (D.D.C. 1956).

101137 F. Supp. 385 (D.D.C. 1956).

102 The Chief Judge cited Ellison v. United States, 206 F.2d 476 (D.C. Cir. 1953), in which Judge Washington upheld a peaceful entry to arrest on probable cause without a warrant.

103235 F.2d 116, 117 (5th Cir.) (per curiam), cert. denied, 352 U.S. 879 (1956). 
the use of excessive, that is unnecessary, force is in any case to be deprecated, evidence under a valid warrant is not thereby made inadmissible." The District of Columbia Circuit, however, reached a contrary result in Woods $v$. United States, ${ }^{104}$ where a search warrant for gambling paraphernalia was executed by forcing open a door without an announcement. Relying on the language of section 3109 (by use of a negative pregnant) and a prior civil case, ${ }^{105}$ Judge Burger found the entry illegal and ordered the evidence suppressed.

\section{B. The Rule in California}

Forcible entry to make an arrest is governed by statute in California. Section 844 of the California Penal Code provides in part: "To make an arrest . . . a peace officer . . . may break open the door . . . after having demanded admittance and explained the purpose for which admittance is desired." The two leading cases interpreting this section are People v. Martin ${ }^{108}$ and People v. Maddox ${ }^{107}$ decided by the California Supreme Court in 1955 and 1956. Martin was arrested twice by the Los Angeles police for bookmaking. There was no forcible entry during the first arrest. The second arrest took place in the following fashion. One officer looked through a window and saw Martin making book. He raised the window, identified himself, and asked Martin to open the door. When Martin did not, the officer entered and made the arrest. It was contended on appeal that the arrest was unlawful under section 844 . Justice Traynor's answer was straightforward. A statement of purpose is not required where the purpose is "reasonably apparent." $\mathrm{He}$ found it immaterial, moreover, that the identification took place after, not before, the window was raised.

The Maddox arrest took place in a somewhat similar fashion. Having probable cause to arrest for a narcotics violation, an Oakland police officer went to Maddox's home and knocked on the door. $\mathrm{He}$ then heard retreating footsteps and a voice say, "Wait a minute." The officer immediately kicked the door open and caught Maddox running toward the bedroom with narcotics paraphernalia in his hands. It was

104240 F.2d 37 (D.C. Cir. 1956), cert. denied, 353 U.S. 941 (1957).

105 Palmer v. King, 41 App. D.C. 419 (1914) (entry with force to execute a writ of replevin held illegal). It is interesting that Judge Burger could find no difference between the possible application of the rule in civil and criminal cases. Woods v. United States, 240 F.2d 37, 40 (D.C. Cir. 1956).

10645 Cal. 2d 755, 290 P.2d 855 (1955).

10746 Cal. 2d 301, 294 P.2d 6, cert. denied, 352 U.S. 858 (1956); see People v. Carswell, 51 Cal. 2d 602, 335 P.2d 99 (1959) (entry by use of key to make arrest after no response to announcement of identity upheld, although no one was present); People v. Hammond, 54 Cal. 2d 846, 357 P.2d 289, 9 Cal. Rptr. 233 (1960) (narcotic addict in possession of gun; court noted danger and possibility of evidence destruction). See generally Fricke, California Criminal Evidence 432-33 (5th ed. 1960). 
contended on appeal that the arrest was illegal under section 844. All parties conceded that there had been no demand for admission or explanation of purpose.

In Maddox, unlike Martin, the court had to consider squarely the effect of a failure to comply with the express terms of the statute. Refusing to order the evidence suppressed, Justice Traynor pointed out that when the right to invade an individual's privacy is clearly apparent, there is no compelling need for strict compliance with the requirement of announcement to protect basic constitutional guarantees. ${ }^{108} \mathrm{He}$ also recognized the inherent difficulty in demonstrating the causal relation between failure to announce and a subsequent seizure of evidence. ${ }^{109}$ Ultimately, however, his opinion rested on the simple proposition that section 844 was a codification of the common law and was subject to the common-law qualifications. ${ }^{110} \mathrm{He}$ held that an announcement under section 844 is excused when an officer believes in good faith that it would increase the possibility of peril, facilitate an escape, or result in the destruction of evidence which would otherwise be seized.

Under the destruction of evidence exception announced in Maddox, the lower appellate courts in California had, prior to 1958, upheld a number of convictions on evidence which otherwise would have been burned up, ${ }^{111}$ ground up, ${ }^{112}$ or flushed away. ${ }^{113}$ It was also held that a

$108 \mathrm{He}$ felt that no basic constitutional right was involved when an officer succeeds in getting where he is entitled to be more quickly than if he had made an announcement under CAI. PEN. CODE $\$ 844$. People v. Maddox, 46 Cal. 2d 301, 306, 294 P.2d 6, 9, cert. denied, 352 U.S. 858 (1956).

109 Illegal conduct unrelated and collateral to the obtaining of evidence in question will not affect its admissibility in California. See People v. Boyles, $45 \mathrm{Cal}$. 2d 652,290 P.2d 535 (1955).

110 At this point Justice Traynor relied on Restatement, Torts $\$ 206$, comment $d$ (1934) which provides:

Since under ordinary circumstances it is reasonable to give the possessor [of property] an opportunity to permit the actor to enter peaceably and thus avoid the danger of harm to the premises and risk of the actor's use of force to the person, it is usually a prerequisite to making a forcible entry into a dwelling that the actor shall first explain his errand and make demand upon the possessor to permit him to enter and make the arrest or other apprehension. Upon refusal of such demand, or if no refusal be made by word or act upon the expiration of a reasonable time, the privilege to effectuate a forcible entry arises. Such reasonable time would ordinarily be very brief.

If for any reason an explanation of his errand and demand for admittance by the actor are or reasonably appear to him to be impracticable, as where such explanation and demand would tend to frustrate or to make such more dangerous to life or limb the arrest or other apprehension, the above requirements may be dispensed with.

111 People v. Hudak, 149 Cal. App. 2d 88, 307 P.2d 942 (Dist. Ct. App. 1957) (bookmaking).

112 People v. Moore, 140 Cal. App. 2d 870, 295 P.2d 969 (Dist. Ct. App. 1956) (bookmaking).

113 People v. Steinberg, 148 Cal. App. 2d 855, 307 P.2d 634 (Dist. Ct. App. 1957) (bookmaking). 
prior criminal record might establish a possibility of peril to justify entry without announcement. ${ }^{114}$ Interestingly enough, of the thirteen reported arrest cases during this period, all but two dealt with narcotics or gambling violations. ${ }^{115}$

California also apparently follows the general rule that entry by trick or subterfuge does not constitute a "breaking." 116

\section{Miller v. United States}

\section{A. The Facts}

Just what happened at the door of "Blue" Miller's apartment will probably never be known. The whole episode could only have involved a few seconds. Following the arrest of "Bessie" Byrd's seventeen-year-old brother, police officers ${ }^{117}$ went to Byrd's and Miller's Washington apartment intending to arrest them. Miller and Byrd were wholesale narcotics dealers, and Byrd's brother was one of their peddlers. Arriving at the apartment, one of the officers knocked on the door, and in a low voice replied-"Police"-to the inquiry"Who's there?". Miller then opened the door slightly on an attached night chain. When he saw the officers he started to close the door. ${ }^{118}$

114 See People v. Ramsey, 157 Cal. App. 2d 178, 320 P.2d 593 (Dist. Ct. App. 1958) (one prior conviction and one prior release with high bail at time of arrest); People v. Potter, 144 Cal. App. 2d 350, 300 P.2d 889 (Dist. Ct. App. 1956) (four previous robberies and one escape conviction).

115 People v. Cahill, 163 Cal. App. 2d 15, 328 P.2d 995 (Dist. Ct. App. 1958) (narcotics); People v. Miller, 162 Cai. App. 2d 96, 328 P.2d 128 (Dist. Ct. App. 1958) (narcotics); People v. Ramsey, 157 Cal. App. 2d 178, 320 P.2d 592 (Dist. Ct. App. 1958) (abortion); People v. Morris, 157 Cal. App. 2d 81, 320 P.2d 67 (Dist. Ct. App. 1958), cert. denied, 358 U.S. 935 (1959) (narcotics); People v. Barnett, 156 Cal. App. 2d 803, 320 P.2d 128 (Dist. Ct. App. 1958) (narcotics) ; People v. Sakelaris, 154 Cal. App. 2d 244, 315 P.2d 902 (Dist. Ct. App. 1957) (bookmaking); People v. Ferrera, 149 Cal. App. 2d 850, 309 P.2d 533 (Dist. Ct. App. 1957) (bookmaking); People v. Guerrera, 149 Cal. App. 2d 133, 307 P.2d 940 (Dist. Ct. App. 1957) (narcotics); People v. Hudak, 149 Cal. App. 2d 88, 307 P.2d 942 (Dist. Ct. App. 1957) (bookmaking); People v. Steinberg, 148 Cal. App. 2d 855, 307 P.2d 634 (Dist. Ct. App. 1957) (bookmaking) ; People v. Potter, 144 Cal. App. 2d 350, 300 P.2d 889 (Dist. Ct. App. 1956) (armed robbery); People v. Moore, 140 Cal. App. 2d 870, 295 P.2d 969 (Dist. Ct. App. 1956) (bookmaking); People v. Sayles, 140 Cal. App. 2d 657, 295 P.2d 579 (Dist. Ct. App. 1956) (narcotics).

116 See People v. Scott, 170 Cal. App. 2d 446, 339 P.2d 162 (Dist. Ct. App. 1959), cert. denied, 361 U.S. 937 (1960) ; People v. Lawrence, 149 Cal. App. 2d 435, 308 P.2d 162 (Dist. Ct. App. 1959).

117 The group of officers included members of the Metropolitan Washington Police Department, Federal Bureau of Narcotics agents, and two narcotic trainees of the Virginia State Police. Miller v. United States, 357 U.S. 301, 303 n.1 (1958).

118 During the trial the officer testified he also said at this point, "Police, you are under arrest, we want in." It would have been proper, in view of this testimony, to remand the case for reconsideration by the trial judge. See Masiello v. United States, 304 F.2d 399 (D.C. Cir. 1962). But neither on appeal nor certiorari was this course of action urged by the Government. The Supreme Court apparently took the position that the Government was willing to have the case decided solely on the pretrial record which did not include the trial statement. 357 U.S. at 304 n.3. 
One officer immediately grabbed the door and forced it open by breaking the night chain. The officers had neither search nor arrest warrants. Miller and Byrd were arrested and marked informant money was found when the apartment was searched.

A pretrial motion to suppress the money was denied. ${ }^{119}$ The trial judge refused to reconsider the question of suppression, and Miller and Byrd were duly found guilty of violating the narcotics laws. ${ }^{120}$ The conviction was affirmed on appeal ${ }^{121}$ and the Supreme Court granted certiorari. ${ }^{122}$

\section{B. Argument of Counsel for Miller}

Miller's appeal was made in forma pauperis. The main proposition of his brief was that breaking and entering without notice of purpose was illegal and in violation of the fourth amendment. ${ }^{123} \mathrm{He}$ began his argument by stating that the chief purpose of the entry into Miller's apartment was to search for the marked informant money. ${ }^{124}$ He then drew the Court's attention to section 3109. Recognizing that section 3109 by its terms applied to search warrants, Miller advanced the proposition that it would be "illogical and unreasonable" to suppose that Congress had intended a lesser standard to obtain when an entry was made without a warrant, albeit to arrest. ${ }^{125}$

Miller did not, however, end his argument at that point. $\mathrm{He}$ suggested that if section 3109 was inapplicable, the case should be decided under United States $v . D i R e^{126}$ on the basis of the law of the District of Columbia, the place where the arrest occurred. ${ }^{127}$ This argument brought into play Accarino v. United States ${ }^{128}$ and its progeny. The remainder of the brief on this point merely reviewed these authorities. ${ }^{129}$ Miller concluded with the suggestion that since

119 Judge Holtzoff heard the motion to suppress. He found the arrest adequately supported by probable cause. He ruled, therefore, that the arrest and incidental search were legal. Record, p. 34. The question of announcement was not argued in the motion.

12018 U.S.C. $\S 371$ (1958) ; 70 Stat. 570 (1956), 21 U.S.C. $\$ 174$ (1958); 68 Stat. 1004 (1954), 26 U.S.C. \$ 4704(a) (1958).

121 Shepherd v. United States, 244 F.2d 750 (D.C. Cir. 1956), rev'd sub nom. Miller v. United States, 357 U.S. 301 (1958).

122353 U.S. 957 (1957).

123 Brief for Petitioner, p. 18. The brief also presented the arrest as a pretext to permit search argument, citing such cases as Henderson v. United States, 12 F.2d 528 (4th Cir. 1926), and the standard pretext language from United States v. Lefkowitz, 285 U.S. 452,467 (1932).

124 Brief for Petitioner, p. 18.

125 Id. at 23-24.

126332 U.S. 581 (1948).

127 Brief for Petitioner, p. 24.

128179 F.2d 456 (D.C. Cir. 1949).

129 Brief for Petitioner, pp. 25-28. 
the law provided no sanction against the officer, one must be assessed against the Government. ${ }^{\mathbf{1 3 0}}$ For this point, he relied on People v. Cahan, ${ }^{131}$ the case in which the California Supreme Court first adopted the exclusionary rule for the express reason of deterring unlawful search and seizure, and Nueslein v. District of Columbia. ${ }^{132}$ His parting word was that, since the evidence was secured "as a result of" the illegal action, it must be suppressed. ${ }^{133}$

\section{Argument of Counsel for the United States}

Contrary to Miller's counsel, the Government viewed the basic question to be one of probable cause. ${ }^{134}$ It proceeded to show that the officer had probable cause, and therefore the right to make an arrest without a warrant, and that an immediate arrest in Miller's apartment was justified. ${ }^{135}$ To support its position the Government relied on cases such as Trupiano $v$. United States ${ }^{\mathbf{1 3 6}}$ and Brinegar $v$. United States. ${ }^{137}$ Johnson $v$. United States ${ }^{138}$ and McDonald $v$. United States ${ }^{139}$ were distinguished since the entering officers in those cases did not have probable cause to arrest. ${ }^{140}$ Having thus established the right to arrest-at least to its own satisfaction-the Government moved on to consider the question of the forcible entry.

The Government first attempted to show the existence of the right to enter by force. The federal and state cases on the issue were reviewed and cited at length. ${ }^{141}$ Accarino $v$. United States ${ }^{142}$ and other similar cases were treated as dealing primarily with subterfuge searches. ${ }^{143}$ Inexplicably, the Government began its answer to Miller's argument on the issue of notice by agreeing "that the validity of the entry should be tested under the standard of 18 U. S. C. 3109." 144 It disagreed, however, that "the arresting officers did not comply with the terms of the statute." 145 Initially, the Government noted that the

$130 I d$. at 29.

13144 Cal. 2d 434, 282 P.2d 905 (1955).

132115 F.2d 690 (D.C. Cir. 1940).

133 Brief for Petitioner, p. 30.

134 Brief for Respondent, p. 12.

$135 \mathrm{Id}$. at $13-18$.

136334 U.S. 699 (1948), cited in Brief for Respondent, p. 13.

137338 U.S. 160 (1949), cited in Brief for Respondent, p. 16.

138333 U.S. 10 (1948).

139335 U.S. 451 (1948).

140 Brief for Respondent, p. 17.

141 Id. at 19.

142179 F.2d 456 (D.C. Cir. 1949).

143 Brief for Respondent, p. 21.

144 Id. at 23.

145 Ibid. 
officers had identified themselves as police. The issue was thus narrowed to the question of whether the circumstances themselves gave adequate notice of purpose. ${ }^{148}$ The Government argued that when "split-second action is necessary, the law does not require an extended exposition of the obvious." 147 The Government relied on previous events of the evening and the very fact of police presence to support the inference of knowledge already possessed. The dictum in Accarino v. United States ${ }^{148}$ was cited for the proposition that announcement and refusal was not necessary when it was already understood. ${ }^{148}$ Finally, the Government sought ${ }^{150}$ to sustain the search by placing it within the search incident to an arrest category under United States v. Rabinozwitz. ${ }^{151}$

Since the Government had conceded that section 3109 controlled the arrest, and had asserted that an adequate announcement had been made, no attention was given to an independent formulation of the requirements of notice, either under the law of the District of Columbia or the fourth amendment, nor was attention given to possible exceptions to the general rule, or appropriate sanctions when the rule, whatever its source, was not obeyed.

\section{Sources of the Standard and Remedy}

It is important to recognize that Miller presented more than just a problem of formulating a substantive rule dealing with announcement and entry. Almost as significant would be the grounds on which the Court would base the rule and the remedy it would fashion. Generally speaking, the Court had four options in choosing the source. Each would have varying consequences.

\section{The Fourth Amendment}

Analytically and abstractly, the fourth amendment consists of two separate clauses. ${ }^{152}$ The first comprehensively subjects searches and

146 Id. at 24-25. The Government also noted that there was testimony at the trial that identity and purpose were expressly announced and that the court of appeals could have passed on the whole record. The question, however, apparently was not brought to the Court's attention as a ground for decision. Id. at 25 n.11.

$147 \mathrm{Id}$. at 26.

148179 F.2d 456, 463 (D.C. Cir. 1949).

149 Brief for Respondent, p. 26.

150 Id. at $27-29$.

151339 U.S. 56 (1950).

152 The fourth amendment provides:

The right of the people to be secure in their persons, houses, papers, and effects, against unreasonable searches and seizures, shall not be violated, and no Warrants shall issue, but upon probable cause, supported by Oath or affirmation, and particularly describing the place to be searched, and the persons or things to be seized. 
seizures to a rule of reasonableness; the second sets out in detail specific requirements for the issuance of warrants. As such, the amendment represents an overriding commitment to a fundamental limitation on official power to arrest, search, and seize. ${ }^{153}$

That the Supreme Court had not by 1958 squarely considered a question of entry is indeed surprising. It had considered such diverse aspects of arrest, search, and seizure as the waivable character of rights the amendment was designed to secure, ${ }^{\mathbf{1 5 4}}$ the character of the individuals who could ${ }^{155}$ or could not ${ }^{156}$ violate its provisions, the nature of probable cause ${ }^{157}$ and its duration in time, ${ }^{158}$ the specificity of the description of the person ${ }^{159}$ to be seized or the place ${ }^{160}$ to be searched, the nature of the prohibited invasion, ${ }^{161}$ the kinds ${ }^{162}$ and quantity ${ }^{163}$ of seizable property, the area or areas within ${ }^{164}$ and outside ${ }^{165}$ its protection, and the nature ${ }^{166}$ and scope ${ }^{167}$ of the remedy to be applied for a violation of its mandate.

153 That each clause of the amendment should be read separately was not clear until United States v. Rabinowitz, 339 U.S. 56 (1950), in which the Supreme Court worked a fundamental change in fourth amendment theory. The amendment, which had previously been tacitly viewed as always requiring a warrant, was no longer subject to historical "exceptions" such as the warrantless search incident to an arrest, or a similar search of an automobile; the exceptions were to be drawn into the reasonableness clause itself. See generally Note, Search and Seizure in the Supreme Court: Shadows on the Fourteenth Amendment, 28 U. CHr. L. REv. 664, 678-86 (1961), and cases and authorities cited therein. See also Lopez v. United States, 373 U.S. 427, 454-55 (1963) (Brennan, J., dissenting).

154 See, e.g., Albrecht v. United States, 273 U.S. 1 (1927) (defects in arrest warrant held waived).

155 Weeks v. United States, 232 U.S. 383 (1914) (application held limited to federal officers), overruled, Elkins v. United States, 364 U.S. 206 (1960) (state search held subject to federal rule for use in federal court).

156 See, e.g., Burdeau v. McDowell, 256 U.S. 465 (1921) (private seizure held outside scope of fourth amendment).

157 See, e.g., Brinegar v. United States, 338 U.S. 160 (1949) (described as nontechnical, reasonable concept).

158 See, e.g., Sgro v. United States, 287 U.S. 206 (1932) (evidence must be fresh). 159 See, e.g., West v. Cabell, 153 U.S. 78 (1894) (must be sufficiently definite). 160 See, e.g., Steele v. United States, 267 U.S. 498 (1925) (description held sufficiently definite).

161 See, e.g., Olmstead v. United States, 277 U.S. 438 (1928) (limited to physical intrusion).

162 See, e.g., Gouled v. United States, 255 U.S. 298, 309-10 (1921) (mere evidentiary items not subject to seizure).

163 See, e.g., Kremen v. United States, 353 U.S. 346 (1957) (seizure of contents of whole house excessive).

164 See, e.g., Taylor v. United States, 286 U.S. 1 (1932) (garage included).

165 See, e.g., Hester v. United States, 265 U.S. 57 (1924) (abandoned property in open field excluded).

166 See, e.g., Weeks v. United States, 232 U.S. 383 (1914) (illegally seized evidence suppressible).

16 See, e.g., Silverthorne Lumber Co. v. United States, 251 U.S. 385 (1920) (evidence suppressible if secured through use of illegally seized evidence). 
The relationship between the castle maxim, as expanded, ${ }^{168}$ and the amendment was obvious. The Supreme Court itself had, for example, approved Thomas Cooley's 1868 observation ${ }^{169}$ that the maxim was part and parcel of the amendment. ${ }^{170}$ It is therefore difficult to see how, under the rationale of Rabinozvitz, ${ }^{171}$ it could realistically be contended that the manner of entry was outside the limitation of reasonableness in the first clause of the amendment. Nevertheless, the closest the Court had come to the question was the dictum of Mr. Justice Bradley in Boyd v. United States ${ }^{172}$ that breaking was but a "circumstance of aggravation" in an unlawful search and seizure. Like Cooley's observation, this dictum was potentially significant. What could be a "circumstance of aggravation" surely ought to be subjected to definite limitations. ${ }^{173}$

Similar language also appears in Rochin v. California ${ }^{174}$ in which the Court was faced with a search and seizure question under the fourteenth amendment. Yet, as the ultimate issue in Rochin aptly illustrated, if the decision were rested on the fourth amendment, ramifications beyond the immediate case had to be considered. What effect would a rule based on the fourth amendment have on the states? Wolf $v$. Colorado had held that the core concept of privacy of the amendment was applicable against the state under the due process clause of the fourteenth amendment. ${ }^{175}$ What relation would this concept have to announcement and entry? Would the decision have the normal retroactive effects of most constitutional decisions? Would it be better to rest the decision on a basis which could, without fundamental implications, be changed or altered either by the Court itself or Congress as practical experience was acquired? The Court had taken a nonconstitutional course in Jencks $v$. United States ${ }^{176}$ and

168 Unquestionably, the castle maxim has come to stand for a pervasive commitment to privacy. Historically, however, it had no such broad meaning; it was, for the most part, limited to the question of lawful entry in the context of the administration of the civil law.

169 Cooley, Constitutional Limitations 611 (8th ed. 1927).

170 Weeks v. United States, 232 U.S. 383, 390 (1914).

171339 U.S. 56,63 (1950).

172116 U.S. 616,630 (1886) (dictum).

173 On the other hand, if a breaking was only a "circumstance of aggravation" did it not, therefore, assume an otherwise unlawful entry? And, if so, would breaking alone be a legally cognizable injury to some "right"?

174342 U.S. 165,172 (1952).

175338 U.S. 25, 27-28 (1949) (dictum). The Wolf decision was overruled subsequently in Mapp v. Ohio, 367 U.S. 643 (1961). Under Wolf only the substantive right of privacy extended through the fourteenth amendment to the states. Under Mapp both the right and the remedy of suppression under the fourth amendment have been incorporated into the fourteenth amendment, and under $\mathrm{Ker} v$. California the standard of the fourth amendment is now also enforceable against the states.

178353 U.S. 657 (1957). 
Congress had immediately enacted a comprehensive statute to regulate the production of investigative reports, an action the Court could not do in the context of a single case. ${ }^{177}$ Finally, of course, there was always the familiar injunction of prudence that constitutional decisions ought to be avoided when there is an independent basis for the decision. ${ }^{178}$

\section{18 U.S.C. $\S 3109$}

It was also possible for the Court to use section 3109 as the basis of the decision. The statute, by its terms, applied only to search warrants, but the Court could have extended it to any breaking in which property was seized. Such a ruling would create a uniform standard applicable to federal arrests made anywhere in the United States and would eliminate the distinction between the execution of search warrants and the making of an arrest. By relying on a statute, the Court would leave Congress the opportunity of enacting comprehensive legislation based on further experience. Finally, such a decision would not effect state procedure, nor would it necessarily pose problems of retroactivity.

\section{Federal Rules of Criminal Procedure}

The Federal Rules of Criminal Procedure provided a similar basis on which to rest the decision. Contrary to what might have been expected, the rules were silent on this question. Rule 57(b), however, provided: "If no procedure is specially prescribed by rule, the court may proceed in any lawful manner not inconsistent with these rules or with any applicable statute." Prior to the adoption of the rules, it was the usual custom to conform federal procedure to state procedure; this rule was designed to guarantee that such a practice would no longer prevail. ${ }^{179}$ Although it could be argued that the question of announcement and entry was not within the intent of the rule, at least one authoritative treatise had observed that rule 57(b) was intended to apply to arrests. ${ }^{180}$ Using rule 57 (b) would be preferable to resting the decision on section 3109 since it would achieve much the same result without the strained construction required to use that section.

17718 U.S.C. $\$ 3500$ (1958).

178 E.g., Peters v. Hobby, 349 U.S. 331, 338 (1955).

179 See Fen. R. CRIM. P. 57(b), Advisory Committee note; cf. United States v. Ewing, 140 U.S. 142 (1891).

180 Whitman, Federal Criminal Procedure 22 (1950). 


\section{State Procedure}

It was also possible for the Court to follow the broad principle announced by Mr. Justice Jackson in United States v. Di Re: ${ }^{181}$

We believe, however, that in absence of an applicable federal statute the law of the state where an arrest without warrant takes place determines its validity. By one of the earliest acts of Congress, the principle of zehich is still retained, the arrest by judicial process for a federal offense must be "agreeable to the usual mode of process against offenders in such state." There is no reason to believe that state law is not an equally appropriate standard by which to test arrests without warrant, except in those cases where Congress has enacted a federal rule. Indeed the enactment of a federal rule in some specific cases seems to imply the absence of any general federal law of arrest. ${ }^{\mathbf{1 8 2}}$

Under $D i R e$ the controlling law is that of the place where an arrest is made. The law of the District of Columbia would therefore, apply to Miller's arrest. The chief vice here, however, is that the question of entry for federal arrest and searches would be subjected to the varying and uncertain standards of state law.

\section{The Remedy}

Assuming the Court held the entry to be improper, the most obvious remedy was to suppress the improperly obtained evidence. ${ }^{183}$

Although English law had left the debtor with only an action in trespass, ${ }^{184}$ the "suppression sanction" had been used in entry situations in early American law. In 1831, the Massachusetts Supreme Court in Ilsley $v$. Nichols held invalid a civil attachment perfected by an unlawful forcible entry on the ground that any other decision "would afford a direct encouragement to the rash and turbulent creditor to violate the rules of law . . . ."185 In People v. Hubbard, ${ }^{186}$ in which New York adopted the Ilsley rule, Judge Cowen forcefully observed: "It is idle and absurd to talk of the privilege [of the house], unless it be enforced by adequate sanctions."

The Supreme Court, however, was squarely faced with one of its own decisions which pointed away from suppressing the evidence. In

181332 U.S. 581 (1948).

$182 \mathrm{Id}$. at 589-90. (Emphasis added.)

183 The possibility of something like a contempt citation is so unlikely that it does not merit discussion.

184 See, e.g., Percival v. Stamp, 9 Ex. 167, 156 Eng. Rep. 71 (1853) (civil execution on personal property).

18529 Mass. 270, 277 (1831).

18824 Wend. 369, 373 (N.Y. 1840) ; accord, Baily v. Wright, 39 Mich. 96 (1878). 
McGuire v. United States, ${ }^{187}$ prohibition agents had destroyed part of the liquor they had otherwise lawfully seized and the Court refused to suppress the retained liquor as a sanction to enforce a statute making it a crime to willfully execute a warrant with "unnecessary severity." 188 Mr. Justice Stone observed that the unlawful destruction had "at most a remote and artificial bearing upon the right of the government to introduce in evidence" ${ }^{189}$ what was otherwise retained. He commented that a "criminal prosecution is more than a game in which the Government may be checkmated and the game lost merely because its officers have not played according to rule." 190

McGuire was closely related to Miller. Unlawful force at the door would be difficult to distinguish from unlawful force after entry, ${ }^{101}$ and there is no logical connection between the seizure of evidence and violent entry. The rule under section 3109 , or section 3109 itself, does not appear to be of a higher order than 18 U.S.C. $\S 2234 .{ }^{192}$ The principle of section 2234, however, might be distinguished from the principle of section 3109 on the grounds of an existing criminal penalty and the requirement of willfulness. Or the Court might find a new rationale for the rule of section 3109 different from the obvious violence rationale of section 2234 .

\section{E. The Court's Opinion}

Mr. Justice Brennan quickly narrowed the issues before the Court to the sole question of proper announcement. Before discussing this issue, however, he set out the source of the law against which the entry was to be judged and explained why the Court wanted to decide the Miller case. Relying on United States $v$. Di Re, ${ }^{193}$ he held that the validity of Miller's arrest must be determined "by reference to the law of the District of Columbia." $194 \mathrm{He}$ justified the Court's review of what, under this holding, would have been purely a local question on the ground that the criteria of the local rule dealing with arrests were "identical with those embodied in 18 U.S.C. $\$ 3109$, which deals

187273 U.S. 95 (1927).

188 Id. at 98 n.1; Espionage Act of 1917, ch. 30, tit. XI, §21, 40 Stat. 230.

189 McGuire v. United States, 273 U.S. 95, 98 (1927).

$190 \mathrm{Id}$. at 99.

191 The thrust of $M c$ Guire is against suppression as an indirect sanction to enforce compliance with a criminal statute applicable to law-enforcement agents. Clearly, this aspect of McGuire could not be avoided, yet that the illegality occurred after the seizure and not prior thereto could have served as a basis for avoiding the naked holding of McGuire.

192 Note 188 supra.

193332 U.S. 581 (1948).

194357 U.S. at 306. 
with entry to execute a search warrant." 195 Section 3109, he pointed out, is not "confined in operation to the District of Columbia . . . ." 196

Having thus set the stage, Mr. Justice Brennan began his substantive discussion with a short review of early common-law authorities, noting their disagreement on the right, without a warrant, to break doors to arrest on suspicion of a felony. He then emphasized, however, that there was no disagreement among the early writers that an announcement of authority and purpose was a prerequisite to the right to break and enter ${ }^{197}$ and that this rule was reflected today in the statutes of a number of states. ${ }^{198} \mathrm{He}$ also referred to some of the state decisions ${ }^{199}$ holding that there are exceptions to the general rule, although he recognized that the existence of the exceptions was not before the Court.

According to Mr. Justice Brennan, the rule seemed "to require notice in the form of an express announcement . . . of . . . purpose . . . " 200 He immediately recognized, however, that there might be "facts known" to the officers which would justify them in being "virtually certain" that such an explicit statement would be a "useless gesture." 201 For the remainder of the opinion, Mr. Justice Brennan considered the application of the "virtual certainty" test of the facts before the Court. He concluded that at best the officer could only have been sure Miller knew there were police at his door conducting an investigation. This, he said, fell short of the requirements of the rule. After paying lip service to the needs of society in enforcing the criminal law, he went on to hold that the absence of an announcement of purpose made the entry and the arrest illegal; the evidence, therefore, had to be suppressed. Twice ${ }^{202} \mathrm{Mr}$. Justice Brennan referred to the interest protected by the rule as "privacy," yet he did not elaborate on how the right of privacy was involved in the case. The opinion never dealt specifically with the issue of force nor explained why the evidence had to be suppressed. ${ }^{203}$

195 Ibid.

190 Ibid.

197 A better statement would, of course, be that they had never directly considered the question.

198357 U.S. at 308.

199357 U.S. at 309, citing Read v. Case, 4 Conn. 166 (1822), and People v. Maddox, 46 Cal. 2d 301, 294 P.2d 6 (1956).

200357 U.S. at 309.

201357 U.S. at 310, citing People v. Martin, 45 Cal. 2d 755, 290 P.2d 855 (1955), and Wilgus, Arrest Withont $A$ Warrant, 22 Mich. L. Rev. 541, 798-802 (1924).

202357 U.S. at $307,313$.

203 "This result can be defended only on the conceptual ground that the breaking invalidates the arrest and that the lack of a lawful arrest makes the search unconstitutional." Kaplan, Search and Seizure: A No-Man's Land in the Criminal Law, 49 CAL. L. Rev. 474, 501-02 (1961). 
Mr. Justice Harlan concurred only in the result. Justices Clark and Burton dissented. The crux of Mr. Justice Clark's opinion was that the local rule prior to Miller would not have required an express announcement of purpose in these circumstances. He felt the Court's reading of the facts and the law was an unjustifiable interference in local law hardly warranted by the purported similarity between the local rule and the general federal statute. He also objected to what he termed the Court's acceptance of the Government's "concession" that "the entry must be tested by a federal statute . . . . ." 204

\section{F. Conclusions}

Several tentative conclusions may be drawn from Mr. Justice Brennan's opinion:

(1) The decision stood as a question of District of Columbia law. Neither the fourth amendment nor 18 U.S.C. \$ 3109 were directly involved despite the dissent's loose language on the latter point. Cases arising outside of the District involving no-announcement arrests would, therefore, be handled as a question of state law under $D i R e$.

(2) The rule in the District for arrests, and more than likely under section 3109 for searches there and elsewhere, was that an explicit statement of "identity" and "purpose" would have to be made prior to entering.

(3) No statement of purpose, or perhaps identity, need be made when facts known to the officers made it "virtually certain" that both their identity and purpose was already known.

(4) The broad rule was perhaps subject to qualification when the officers believe in good faith that there was danger of bodily harm, escape, or the destruction of evidence. It was not clear whether the "virtual certainty" test would control a finding of good faith.

(5) Evidence seized after an unlawful entry in a search incident to an arrest will be suppressed. McGuire $v$. United States ${ }^{205}$ was placed in a judicial limbo. Whether it was silently overruled or distinguished could only be established by future litigation.

(6) For the Court, the principle of section 3109, and probably the section itself, was grounded somehow in the concept of privacy and the history of the force rationale was ignored. 


\section{Post-Milier Decisions ${ }^{206}$}

\section{A. Federal Cases}

Since the Supreme Court's decision in Miller, the federal courts have had a field day with unlawful entry questions. They have disagreed, moreover, on some of the most fundamental aspects of the Court's decision. Understandably, the Court of Appeals for the District of Columbia Circuit has shown little sensitivity to the question of the source of the standard set forth in Miller as governing entry to make arrests. Usually, Miller has been referred to without further comment. ${ }^{207}$ The Seventh Circuit in United States $v$. Frier$\operatorname{son}^{208}$ upheld a forcible entry without mention of state law, citing only Miller but distinguishing its facts. The Second Circuit upheld an arrest perfected by a forcible entry in United States $v$. Nicholas ${ }^{209}$ considering the application of section 3109, yet referring also to the Supreme Court's Ker decision. Interestingly enough, the Ninth Circuit has apparently handed down inconsistent decisions. In Hopper v. United States ${ }^{210}$ and Williams $v$. United States, ${ }^{211}$ Washington and California law were held respectively to govern the manner of entry in making an arrest. Both decisions explicitly referred to Miller as District of Columbia law. However, in Munoz v. United States, ${ }^{212}$ the court squarely held an arrest by federal agents without a warrant unlawful under section 3109 as interpreted by Miller. The Sixth Circuit in United States $v$. Sharpe ${ }^{213}$ recognized the problem, but resolved it by finding that the entry before them was lawful by any standard.

The various District Courts which have had to consider entry questions have also indicated some confusion. Judge Watkins in United States $v$. Lawenson ${ }^{214}$ applied Miller to an arrest which oc-

208 No comment will be made here on United States v. Barrow, 212 F. Supp. 837 (E.D. $\mathrm{Pa}$ 1962). As an attorney of record for the United States, in this case, an out of court comment by me would be of questionable propriety under Rule 20 of the Canon of Ethics. Suffice it to say that Judge Joseph Lord's opinion should be consulted by anyone interested in the development of the law in this area.

207 See, e.g., Hair v. United States, 289 F.2d 894 (D.C. Cir. 1961) ; Williams v. United States, 276 F.2d 522 (D.C. Cir. 1960), reversing United States v. Murphy, 174 F. Supp. 823 (D.D.C. 1959). But see Wayne v. United States, No. 16709, D.C. Cir., April, 1963, p. 12.

208299 F.2d 763 (7th Cir. 1962).

209319 F.2d 697 (2d Cir. 1963).

210267 F.2d 904 (9th Cir. 1959).

211273 F.2d 781 (9th Cir. 1959).

212 No. 18,488, 9th Cir., Nov. 29, 1963. See also Leahy v. United States, 272 F.2d 487 (9th Cir.), cert. granted, 363 U.S. 810 (1960), dismissed by stipulation, 364 U.S. 945 (1961).

213 No. 15129 , 6th Cir., August 30, 1963, p. 5.

214 No. -, D. Md., April 13, 1960 (unreported). 
curred in Maryland. Judge Roth in United States v. Wakefield ${ }^{215}$ followed the suggestion of an Assistant United States Attorney and held that under Miller section 3109 governed an arrest which occurred in Michigan. Only one District Court has explicitly recognized the real character of Miller. In United States v. Macri, ${ }^{216}$ Judge Smith, relying on United States $v . D i R e^{217}$ and Miller itself, held that Connecticut law governed an arrest which occurred in that state.

What constitutes "breaking" within the rule, whatever its source, has also been the subject of some disagreement. Although both Williams and Hopper were decisions applying state law, each referred to Miller as a case dealing with forcible entry. The court in Williams was therefore able to uphold an entry through a shut but unlocked door and in Hopper to uphold an entry through an open door. In United States $v$. Silverman, ${ }^{218}$ Judge Holtzoff agreed with the Ninth Circuit and referred to Miller as a case limited to forcible entry. On the other hand, Judge Bazelon, in Hair v. United States, ${ }^{219}$ following a privacy rather than a force approach, remarked that it made no difference if the door "was locked, closed but unlocked, or merely left ajar." 220 Apparently he would view any entry without proper announcement as illegal. Judge Smith in Macri observed that the use of force was not "a significant factor in the Miller case." 221 Judge Watkins in Lazerenson held that an entry obtained by getting a hotel employee to unlock a door was a "breaking," and Judge Roth in Wakefield felt that when a door opened from the mere force of knocking a "breaking" had occurred.

Entry obtained by misrepresentation of identity without force, on the other hand, was upheld in Leahy $v$. United States. ${ }^{222}$ It is not entirely clear, however, whether Judge Orr's position was that the entry was not a "breaking" and therefore not within the rule, or whether he merely considered it a justifiable exception to the general rule. After observing that misrepresentation of identity is not a breaking, he went on to justify the use of the strategem. Such justification would not, of course, have been necessary unless some exception to a general rule was involved.

215 No. - E.D. Mich., July 2, 1962 (unreported).

216185 F. Supp. 144 (D. Conn. 1960), cf. 36 Notre Dame Law. 432 (1961). 217332 U.S. 581 (1948).

218166 F. Supp. 838, 841 (D.D.C. 1958), aff'd, 275 F.2d 173 (D.C. Cir. 1960), rev'd on other grounds, 365 U.S. 505 (1961).

219289 F.2d 894 (D.C. Cir. 1961).

220 Id. at 897.

221185 F. Supp. 144, 149 (D. Conn. 1960).

222272 F.2d 487 (9th Cir. 1959). See note 212 supra. 
The existence or absence of exceptions to the rule has itself been the subject of comment. Judge Swygert in Frierson used Miller as authority to uphold a forcible entry when no announcement of purpose had been made on the ground that there was a "virtual certainty" that purpose was known. In Nicholas, the Second Circuit likewise found that any announcement in similar circumstances would have been a "useless gesture." The Sixth Circuit in Sharpe also upheld a forcible entry after only an announcement of identity when it was immediately followed by an indication that evidence subject to seizure was in peril of destruction. Yet these opinions must be compared with Williams v. United States, ${ }^{223}$ which reversed United States $v$. Murphy. ${ }^{224}$ A finding of "virtual certainty" is apparently a difficult task for some judges. Judge Bazelon in Hair, moreover, even observed that it "may be doubted whether Miller is susceptible to such an exception." 225

Judge Watkins in Laverenson also failed to find an exception despite the fact that the FBI agents were arresting an armed bank robber. He observed:

It is probably a matter of no moment, but I disagree violently . . . but I am bound by the [Miller] decision unless or until it is changed . . . I I must, therefore, find that because the FBI agents before they had the door unlocked did not first announce their presence and purpose, and then, but only then, if entrance were not granted, and if they were still alive, either unlock or break down the door, the entry, arrest and seizure were accordingly, illegal. ${ }^{226}$

Judge Smith in Macri also refused to find under Connecticut law an exception warranting no announcement when evidence might be destroyed although evidence had been previously destroyed by the same individual in a similar situation.

A number of cases since Miller have dealt with forcible entries under section 3109. Masiello $v$. United States ${ }^{227}$ makes it clear that the statute requires an announcement of both identity and purpose in the execution of a search warrant. "Breaking" was construed in Keiningham $v$. United States in these terms: ${ }^{228}$

[T] he word "break," as used in 18 U.S.C. $\$ 3109$, means "enter without permission." We think that a "peaceful"

223276 F.2d 522 (D.C. Cir. 1960).

224174 F. Supp. 823 (D.D.C. 1959).

225289 F.2d 894, 896 n.9 (D.C. Cir. 1961).

226 No. - D. Md., April 13, 1960 (unreported). (Emphasis added.)

227304 F.2d 399 (D.C. Cir. 1962), aff'd on appeal follozeing remand, 317 F.2d

121 (D.C. Cir. 1963).

228287 F.2d 126, 130 (D.C. Cir. 1960). 
entry which does not violate the provisions of $\S 3109$ must be a permissive one, and not merely one which does not result in a breaking of parts of the house.

Here again the key is clearly more than the absence of force. The requirement of announcement under section 3109 also has been limited to the initial breaking. ${ }^{229}$

On the question of "refused admittance," Judge Burger aptly observed in the second Masiello v. United States ${ }^{230}$ that

the phrase . . . is not restricted to an affirmative refusal. Indeed it would be an unusual case coming before the courts where an occupant affirmatively "refused admittance" or otherwise made his refusal known verbally after being given notice... .

Silence then may be construed to constitute a "refused admittance" after a reasonable period of time. ${ }^{231}$ The cases have not, however, established a precise time interval. In Masiello I, Judge Burger termed the question a matter of the facts and circumstances of each case. ${ }^{232}$ Forcible entry, moreover, has been sustained when "admittance was not forthcoming ;" 233 after "twenty-five or thirty seconds" no response was heard; ${ }^{234}$ after "about a minute;" ${ }^{235}$ and after "a minute or two." 236

No response plus meaningful noise or its cessation may also indicate refusal. Forcible entry has been sustained when noise heard after announcement was thought to "indicate refusal;" 237 when the

229 United States v. Nicholas, No. 366, 2d Cir., June 26, 1963.

230317 F.2d 121, 122 (D.C. Cir. 1963).

231 United States v. Viale, 312 F.2d 595 (2d Cir.), cert. denied, 373 U.S. 903 (1963); United States v. Whiting, 311 F.2d 191 (4th Cir. 1962), cert. denied, 372 U.S. 935 (1963) ; Sykes v. United States, 312 F.2d 232 (8th Cir.), cert. denied, 373 U.S. 942 (1963).

232304 F.2d 399, 402 (D.C. Cir. 1962) (concurring opinion). "It should be clear that . . [ [the necessary] time lapse [that should occur] between the police announcement and a break-in cannot be rigidly defined . ..." In Masiello v. United States, 317 F.2d 121, 123 n.5 (D.C. Cir. 1963), Judge Burger suggests that it is not "too much to expect that officers .. . take some note of the time." When there is a conflict of testimony, the finding of the hearing judge will be respected if it is supported by substantial evidence, Sykes v. United States, 312 F.2d 232 (8th Cir.), cert. denied, 273 U.S. 942 (1963), or if a fair resolution of the issue of credibility is made, Masiello v. United States, supra.

233 United States v. Purgitt, 176 F. Supp. 557 (D.D.C. 1959).

234 United States v. Gorman, 208 F. Supp. 747, 750 (E.D. Mich. 1962).

235 United States v. Whiting, 311 F.2d 191, 195 (4th Cir. 1962), cert. denied, 372 U.S. 935 (1963).

230 United States v. Viale, 312 F.2d 595, 602 (2d Cir.), cert. denied, 373 U.S. 942 (1963).

237 United States v. Fair, 176 F. Supp. 571, $572-73$ (D.D.C. 1959). 
sound heard prior to announcement stopped; ${ }^{238}$ and when the sound heard after the announcement indicated that the occupants were attempting to destroy evidence. ${ }^{239}$ Relevant in this last situation may be the officers' experience with like attempts in similar cases in the past. Again in Masiello $I I,{ }^{240}$ Judge Burger noted:

Officers of experience with the numbers racket were . . . warranted in believing that the "commotion" which was heard through the door, accompanied by no response following two knocks and one announcement of authority and purpose, meant that the occupants were very likely engaged in what might be called "standard emergency procedure" of destroying the evidence.

Significantly, the Court of Appeals for the District of Columbia has also construed section 3109 in Jones $v$. United States ${ }^{241}$ to permit the use of trick or subterfuge to get the occupant to open the door. ${ }^{242}$ The decision closely parallels Leahy which, of course, dealt with the arrest situation. It should be noted, however, that the decision was five-to-four, and the dissent raised Gouled $v$. United States ${ }^{243}$ as a possible constitutional barrier to the majority opinion. ${ }^{244}$

\section{B. State Cases}

Since Miller, forcible entry questions have been considered in a number of states with California leading the list. Under Maddox, however, the California courts have uniformly refused to grant suppression

238 Sykes v. United States, 312 F.2d 232, 234 (8th Cir.), cert. denied, 373 U.S. 942 (1963).

239 Masiello v. United States, 317 F.2d 121 (D.C. Cir. 1963).

$240 \mathrm{Id}$. at 123.

241304 F.2d 381 (D.C. Cir. 1962), cert. denied, 371 U.S. 852 (1963).

242 It must be added that the Jones case is, at least arguably, open to the interpretation that no trick was used. The "trick" consisted in not telling the occupant that the janitor he asked for was also accompanied by the police.

243255 U.S. 298 (1921).

244 Unanswered to date is the scope of the term "house" under 18 U.S.C. $\$ 3109$ (1958). The provision was based on the New York law. There, Haggerty v. Wilber, 16 Johns. R. 287 (N.Y. Sup. Ct. 1819), which upheld an entry into a nondwelling without announcement, is the leading case. Haggerty, moreover, followed Penton v. Brown, 1 Keble 698, 83 Eng. Rep. 1193 (K.B. 1669), which in turn was purportedly based on Semayne's Case. As a matter of legislative history, therefore, it would seem that "house" within $\$ 3109$ is limited to a family type dwelling. See also the opinion of Lord Mansfield in Lee v. Gansel, 1 Cowp. 1, 98 Eng. Rep. 935, 937-38 (K.B. 1774). The key question, however, is whether the concept of reasonableness in the first clause of the fourth amendment, which now embodies, as we shall later see, the rule of announcement, can be squared with this historical development. The teaching of Carroll v. United States, 267 U.S. 132 (1925), which upheld a similar congressional distinction between an automobile and a dwelling house under the warrant clause, is that the distinction can be sustained.

See also Wayne v. United States, 318 F.2d 205 (D.C. Cir. 1963) (apparent agreement that civil emergency may warrant forcible entry independent of $\$ 3109$ ). 
motions on unlawful entry pleas. ${ }^{245}$ Miller itself was largely ignored in California for the better part of four years. Judge Ford's opinion in People v. Gauthier ${ }^{246}$ is the first reported California case even to cite Miller. The entry in the case was upheld, however, and Miller was referred to as having been decided "from the standpoint of statutory rather than constitutional law." ${ }^{447}$ Nothing in Mapp v. Ohio ${ }^{248}$ was deemed to require a different result. The Texas Court of Criminal Appeals also reconsidered its rule in light of Miller. In $M c$ Cown $v$. State, ${ }^{249}$ the court decided to adhere to its long-standing practice and refused to suppress evidence for nonliteral compliance with Texas' announcement rule. The Tennessee Supreme Court has also decided a post-Miller forcible entry question. In White $v$. State, ${ }^{250}$ it affirmed its former practice without even citing Miller.

Miller has not, however, been completely ignored by the states. In State v. Vuin, ${ }^{251}$ an Ohio court of common pleas rendered an alternative holding, based largely on Miller, that a violation of Ohio's forcible entry statute ${ }^{252}$ warrants the suppression of subsequently obtained evidence. Miller was also felt in New York. ${ }^{253}$ Judge Geller in People v. Cocchiara ${ }^{254}$ discussed the application of section 178 of the Code of Criminal Procedure, which requires announcement prior to forcible entry to arrest, when such an entry was made by deception. While not actually deciding the matter, he apparently did not feel that Miller controlled his decision and indicated that the California rule

245 People v. Bookout, 197 Cal. App. 2d 457, 17 Cal. Rptr. 213 (Dist. Ct. App. 1961) (narcotic arrest); People v. Baca, 197 Cal. App. 2d 362, 17 Cal. Rptr. 204 (Dist. Ct. App. 1961) (burglary arrest) ; People v. Ruiz, 196 Cal. App. 2d 695, 16 Cal. Rptr. 855 (Dist. Ct. App. 1961) (narcotic arrest); People v. Ker, 195 Cal. App. 2d 246, 15 Cal. Rptr. 767 (Dist. Ct. App. 1961), aff'd sub nom. Ker v. California, 374 U.S. 23 (1963) (narcotic arrest) ; People v. Garcia, 187 Cal. App. 2d 93, 9 Cal. Rptr. 493 (Dist. Ct. App. 1960) (narcotic arrest) ; People v. Fisher, 184 Cal. App. $2 d$ 308, 7 Cal. Rptr. 461 (Dist. Ct. App. 1960) (narcotic arrest); People v. Montano, 184 Cal. App. 2d 199, 7 Cal. Rptr. 307 (Dist. Ct. App. 1960) (narcotic arrest); People v. Feeley, 179 Cal. App. 2d 100, 3 Cal. Rptr. 529 (Dist. Ct. App. 1960) (narcotic arrest); People v. Covan, 178 Cal. App. 2d 416, 2 Cal. Rptr. 811 (Dist. Ct. App. 1960) (narcotic arrest) ; People v. Williams, 175 Cal. App. 2d 774, 1 Cal. Rptr. 44 (Dist. Ct. App. 1959) (narcotic arrest); People v. Castro, 176 Cal. App. $2 d$ 325, 1 Cal. Rptr. 231 (Dist. Ct. App. 1960) (narcotic arrest).

246 205 Cal. App. 2d 419, 22 Cal. Rptr. 888 (Dist. Ct. App. 1962) (narcotic arrest).

247 Id. at 425,22 Cal. Rptr. at 892.

248367 U.S. 643 (1961).

249170 Tex. Crim. 142, 338 S.W.2d 732 (1960), cert. denied, 368 U.S. 856 (1961)

(entry after no response to knocking lawful); see Texas cases cited note 84 supra. 250356 S.W.2d 411 (Tenn. 1962) (burglary arrest announcement by police made forcible entry lawful).

25189 Ohio L. Abs. 600, 185 N.E.2d 506 (C.P. 1962).

252 OHio Rev. Cone ANn. $\$ 2935.12$ (Page 1954).

253 Here it is interesting to recall that the federal rule is supposed to reflect

New York law. See note 98 supra.

25431 Misc. 2d 495, 221 N.Y.S.2d 856 (N.Y. County Ct. 1961). 
should be followed. It is not clear from Judge Geller's opinion, however, whether he considered the entry by trick to be an exception, or simply not covered because no "breaking" was involved. In People v. Goldfarb, ${ }^{255}$ however, section 178, on the authority of Miller, was "strictly construed" to require the suppression of gambling paraphernalia seized after police broke into an apartment having only demanded, "Open up." On the other hand, Judge Sobel in People v. Montanaro ${ }^{250}$ commented on the "breaking in" sections of the code in these terms:

[I] $t$ should be noted that the Miller decision is not of constitutional dimension. It interpreted a Federal Statute not the Fourth Amendment. Most States . . . have excused compliance with "breaking in" statutes under "exigent circumstances" . . . . It is suggested . . . when a search warrant is directed against easily disposable contraband the police officers need only make a conscientious effort to enter peaceably and if there is no response to the knock or oral request for admission [they] may use force.

. . [E]xigent circumstances exist when the property sought is easily disposable and there is danger in requiring strict compliance with the "breaking in" requirements of the Code. ${ }^{257}$

It must be noted, of course, that neither Cocchiara, Goldfarb, nor Montanaro is an opinion of the New York Court of Appeals. What that court will have to say about the forcible entry rule and its underlying policy remains to be seen. ${ }^{258}$

In State v. Smith, ${ }^{259}$ the New Jersey Supreme Court upheld the validity of a narcotics conviction when a warrantless arrest had been effected by a forcible entry without an announcement. The court found that the offense was committed in the officers' presence and that they had probable cause to make the arrest. New Jersey has no forcible entry statute and no New Jersey case had previously considered a question of proper announcement, but the court assumed "for present purposes" that Mapp made Miller applicable to the states. Chief Justice Weintraub, writing for the court, then stated:

We must identify precisely what is involved. We are not dealing with the sufficiency of the basis for a search. Prob- 
able cause existed. The right to invade the privacy of the occupant was clear. . . .

The question then is whether the Fourth Amendment intended to nullify the State's clear right to search by imposing a condition which would defeat it. If the State's right to the contraband is to be denied, it must be because of the evident danger and rudeness of a sudden entry. But the danger and the rudeness are not the gratuitous product of official insolence or indifference; they are the consequences of the criminal enterprise, made inescapable by its nature. Moreover, in striking a balance between the right of the State and the rights of the individual, the need to protect the innocent is not a conspicuous factor; for, as we have said, the hypothesis includes the existence of probable cause and indeed a reasonable basis to believe a criminal event is in progress. Hence, to require that admittance be demanded and the mission revealed before entry into the premises would, overall, benefit the guilty alone. It seems to us that the Fourth Amendment does not transmute a "reasonable" search into an "unreasonable" one merely because the officer discharged his duty to arrest and search in a manner which fairly appeared necessary for the successful enforcement of the State's right. ${ }^{260}$

Although the court saw no violation of the fourth amendment in the forcible entry before it, the assumption that Miller was more than a construction of a federal statute or a statement of the common law was commendably farsighted.

\section{The Supreme Court}

The Supreme Court decided only three cases during the postMiller, pre-Ker period in which a Justice had occasion to comment on Miller. ${ }^{261}$ The most significant of the post-Miller comments occurred in Mr. Justice Frankfurter's dissent in Elkins $v$. United States, ${ }^{262}$ which overruled the silver platter doctrine of Weeks $v$. United States. ${ }^{263}$ In an opinion by Mr. Justice Stewart, the Court held that evidence illegally seized by state officers cannot be used in the federal courts. The scope of the majority holding is not entirely clear from the opin-

260 Id. at $499-500,181$ A.2d at 770-71.

$201 \mathrm{Mr}$. Justice Douglas, dissenting, refers to Miller in Wilson v. Schnettler, 365 U.S. $381,395 \mathrm{n} .9$ (1960), in a context of a discussion of the fourth amendment and the right of privacy. He merely cites it, however, as an illustration of one of those cases which follows the rule that illegally seized evidence will be suppressed. Mr. Justice Clark also refers to Miller in Mapp v. Ohio, 367 U.S. 643, 658 (1960), on the point of "shortcut" police methods.

262364 U.S. 206 (1960).

263232 U.S. 383 (1914). 
ion. The test of illegality apparently was based solely on the fourth amendment. A distinction, therefore, could be drawn between evidence illegally seized under the fourth amendment and that illegally seized under statutory or court rules. At any rate, this was Mr. Justice Frankfurter's view of the case. As an illustration of the distinction, he cited "the rules governing the execution of lawful warrants, applied in Miller $v$. United States . . . ." 284 Elkins, however, left unsettled the question of what disposition would be made of evidence, for example, legally secured by state officers under state announcement standards but which would have been illegally secured under comparable federal standards.

Mr. Justice Frankfurter also referred to Miller in Jones v. United States. ${ }^{205}$ In remanding the case for reconsideration of the evidence under section 3109, he noted that Miller made clear that the application of section 3109 was a question of all the facts and circumstances. Unfortunately, he did not make it unequivocally clear that this was true because Miller was a construction of section 3109 or an application of a rule virtually identical but independent of section 3109. Failure to give this kind of attention to his language, it must be noted, is most unusual in an opinion by Mr. Justice Frankfurter. It is, however, characteristic, as we shall see, of almost all of the Court's announcement cases.

In Wong Sun v. United States, ${ }^{266} \mathrm{Mr}$. Justice Brennan referred to his opinion in Miller. He used Miller as an analogy to show that flight is ambiguous when an officer seeking admission does not identify himself and announce his purpose and, therefore, will not warrant an inference of guilt on which a judgment of the existence of probable cause can be made. After making the analogy to justify his finding of ambiguity, however, Mr. Justice Brennan noted that the Government did not claim that the officer's failure to announce his identity at the door was warranted by a possibility of peril or the destruction of evidence. ${ }^{267}$ How this explanation for the failure to announce would

264364 U.S. at 244. The requirement of a written affidavit under Fen. R. CRIM. P. 41 would be another illustration. Compare Giordenello v. United States, 357 U.S. 480 (1958), with Sparks v. United States, 90 F.2d 61 (6th Cir. 1932).

To date, however, it must be observed that the lower federal courts have apparently been oblivious to Mr. Justice Frankfurter's distinction. See, e.g., United States, v. Walters, 193 F. Supp. 788 (W.D. Ark. 1961) (rule 41(e) assumed to be the standard); James v. United States, 280 F.2d 443 (8th Cir. 1960) (18 U.S.C. \$ 3052 (1958) assumed to be the standard). Yet because of the change in law worked by Elkins and, as we shall see, by Mapp-Ker, we can expect that a number of federal problems will receive incidental clarification. The Supreme Court, for example, has never decided what "positive" in nighttime search warrants means under FED. $R$. CrIAr. P. 41 (c).

265362 U.S. $257,272(1960)$.

268371 U.S. 471 (1963).

267 Id. at 484. 
effect the fundamental ambiguity of the accused's reaction is not spelled out. Mr. Justice Brennan did not explicitly hold, moreover, that the entry was unlawful because a proper announcement was not made, and, since the arrest occurred in California, it is not clear how Miller could control this issue. ${ }^{268}$ The best that can be said for this further remark is that it is itself ambiguous. It does, on the other hand, constitute a reference to possible justifications for a failure to announce purpose and identity. To this limited degree, the aside is significant.

Mr. Justice Clark also referred to Miller in his dissenting opinion in Wong Sun, in which Justices Harlan, Stewart, and White joined. Mr. Justice Clark felt that the defendant's flight presented no ambiguity, that there was no basis in Miller for concluding that the accused's retreat from the door was an attempt to repel an unauthorized intrusion, ${ }^{269}$ and that the officer had clearly identified himself. Two other remarks by Mr. Justice Clark in his discussion of Miller have significance beyond the narrow question of the ambiguity of flight. At one point he asked, after noting that the officer had identified himself as a narcotics agent, how "could he more clearly announce himself and his purpose?" 270 Thus, the dissent would apparently be willing to find that purpose may be inferred from a statement of identity. It is difficult to understand how this squares with Miller. Mr. Justice Clark also referred to Miller at another point as a case which "involved interpretation of the law of the District of Columbia." 271 It appears then that the various members of the Court have not finally settled in their own minds the full meaning of Miller. ${ }^{272}$

\section{Ker v. California}

\section{A. The Facts}

Having probable cause to arrest Ker, four Los Angeles County police officers proceeded to his apartment and learned that it was occupied. They then went to the building manager and obtained a pass key to the apartment. One officer was stationed outside the window of the apartment to intercept ejected evidence. The other officers quietly

208 The general question was, however, argued in the briefs. See, e.g., Brief for Respondent, pp. 33-36.

260371 U.S. at 502 (dissenting opinion).

$270 I d$. at 501.

271 Id. at 502 .

272 It should be noted in fairness to the Court and some of the lower court judges that the Bar is not altogether sure what Miller means either. See, e.g., 8 WrGMoRE, EvIDENCE § 2184a (McNaughton rev. 1961) ; Broeder, Wong Sun v. United States: A Study in Faith and Hope, 42 Nen. L. Rev. 483, 503-07 (1963); Kaplan, Search and Seizure: $A$ No-Man's Land in the Criminal Laze, 49 CalrF. L. Rev. 474, 501, $502 \mathrm{n} .183$ (1961). 
unlocked and opened the apartment door and found Ker sitting in the living room. This course of action was taken, it was testified, because of the officer's experience with attempts to destroy evidence. Ker and his wife were arrested, and marijuana was found in the subsequent search.

Ker and his wife were convicted of a violation of California narcotics laws. ${ }^{273}$ The California District Court of Appeals affirmed the conviction, ${ }^{274}$ and the Supreme Court of California denied a petition for hearing without an opinion. The District Court of Appeals, inter alia, found that the entry was lawful under the rationale of Maddox and held that "to have announced themselves and/or delayed entry, the officers would have provided Ker sufficient time within which to dispose of or destroy the narcotics." 275 The Supreme Court subsequently granted certiorari. ${ }^{276}$

\section{B. Argument of Counsel for $\mathrm{Ker}$}

Ker's argument on certiorari need not detain us long. Apart from the question of the standard governing the search and seizure, ${ }^{277}$ he relied primarily on the proposition that a warrantless search had occurred. ${ }^{278}$ For the proposition that such a search is invalid, he cited the standard cases, McDonald v. United States ${ }^{279}$ and Johnson $v$. United States. ${ }^{280}$ The counter-contention that the search might be sustained as incident to the arrest was met by arguing that the officers intended to search rather than arrest. ${ }^{281}$ Here Ker relied on Johnson ${ }^{282}$ and on Lefkowitz $v$. United States. ${ }^{283}$

The possible application of Miller itself, or a rule of announcement, whatever its source, was ignored. Wisely perhaps, the California cases on announcement were not mentioned.

\section{Argument of the American Civil Liberties Union of} Southern California as Amicus Curiae

The crux of the short Amicus brief, like that of Ker's was that the entry had been made to search for evidence, although the ACLU

273 CaI. Hearth \& Safety Code $\$ 11530$.

274 People v. Ker, 195 Cal. App. 2d 246, 15 Cal. Rptr. 767 (Dist. Ct. App. 1962), aff'd sub nom. Ker v. California, 374 U.S. 23 (1963).

275 Id. at 256, 15 Cal. Rptr. at 772-73.

276368 U.S. 974 (1962).

277 Brief for Petitioner, pp. 4-5.

$278 I d$. at $5-7$.

279335 U.S. 451 (1948).

280333 U.S. 10 (1948).

281 Brief for Petitioner, pp. 11, 13.

282333 U.S. at $13-14$.

283285 U.S. 452,467 (1932). 
added that the search might have been for the existence of crime. ${ }^{284}$ The ACLU did, however, address itself to what the Court subsequently considered the core of the matter. It argued that when lawful procedures are available then such clandestine procedures as here descend to the "unreasonable search and seizure prohibited by the Fourth Amendment." 285 This proposition was based, strangely enough, not on Miller, or as part of an otherwise full scale assault on the California announcement cases, but on Gouled $v$. United States ${ }^{288}$ and Johnson v. United States. ${ }^{287}$

Noting that the officers may have been motivated by their knowledge that narcotics are "often disposed easily by flushing down the drains," it was still suggested "that this is preferable to fostering the cancer of this surreptitious, clandestine, stealthy, furtive entry, without a warrant, into a man's home." 288 Again, however, the main thrust of the argument was directed at the right to enter and not the manner of entry, and once it was assumed the entry was to search, however effected, such cases as Agnello $v$. United States ${ }^{289}$ and Taylor $v$. United States ${ }^{290}$ were relied upon for the proposition that probable cause alone would not sustain the search.

\section{Argument of the People of California}

The Attorney General of California divided his brief into two main parts. His argument on the issue of the proper substantive standard to apply under $M a p p$, although persuasive, need not detain us. The Attorney General sought to justify the search and seizure on California and federal cases, where they agreed, and where they disagreed, on the reasonableness of the California view. ${ }^{291}$

After making the obvious point that probable cause to arrest without a warrant existed, ${ }^{202}$ he moved on to deal with the manner of the entry in terms of the California rule under section 844 and People v. Maddox. ${ }^{293}$ The heart of this argument was that the California rule which permitted unannounced entry when there was reasonable belief

284 Brief for the ACLU as Amicus Curiae, p. 4.

285 Id. at 8.

286255 U.S. 298 (1921).

287333 U.S. 10 (1948).

288 Brief for the ACLU as Amicus Curiae, p. 10. It seems appropriate to comment that at this point the Amicus was apparently arguing more by sound and adjective than analysis and reason.

289269 U.S. 20 (1925).

290286 U.S. 1 (1932).

291 Brief for Respondent, p. 17.

292 Id. at $17-21$.

29346 Cal. 2d 301, 294 P.2d 6, cert. denied, 352 U.S. 858 (1956). 
that evidence might be destroyed was reasonable in light of the danger narcotics presented to the "total demolition of the personality" ${ }^{294}$ and the peculiarly vexatious problem California has had as a seacoast state with the narcotics traffic. ${ }^{205}$ The general experience of the officers with attempts to destroy such contraband and the various precautions taken prior to the actual arrest were cited for the existence of the possibility and the good faith of the officers. ${ }^{298}$ Thereafter, the brief presented the standard arguments dealing with searches incident to valid arrests. ${ }^{297}$

\section{E. The Opinion}

Like $M a p p, K e r$ is a graphic illustration of the inability of the Justices to agree in search and seizure cases. The opinion is divided into five parts. Part I deals with the nature of the proper standard applicable under the fourth-fourteenth amendments against the states, an issue left undecided in Mapp. It has the concurrence of all of the Justices save Mr. Justice Harlan. Our attention will be focused on it only to the degree that it is relevant to federal law enforcement when it distinguishes between constitutional and supervisory power to suppress. Part II deals with the question of probable cause, Part III with the method of entry, Part IV with search incident to an arrest, and Part $V$ with an issue not raised by the briefs or considered by the Court. Parts II-V represent the opinion of Justices Clark, Black, Stewart, and White. Mr. Justice Harlan concurred only in result. Justices Brennan, Douglas, Goldberg, and the Chief Justice dissented in a three part opinion. Like the dissent, our primary concern here will be with the issues presented in Part III above.

Mr. Justice Clark began his four-man opinion by referring to the holding of $M a p p$ and noting the irony that the initial test under it came from California, a state which had been commended for having already voluntarily adopted the exclusionary rule. He then carefully pointed out what $M a p p$ did not involve. He recognized the distinction between the operation of the exclusionary rule when it is founded on the Constitution itself rather than the supervisory power of the Court. In the latter category he placed $M c N a b b$, Miller itself, and Nardone. He alluded to the problems of a "healthy federalism" and the "practical demands of effective law enforcement" while commenting that, although the "same fundamental criteria" had to govern both

294 Brief for Respondent at 25.

$295 \mathrm{Id}$. at 14.

296 Id. at 24.

297 Id. at $25-35$. 
state and federal law enforcement activity, there was no "fixed formula" for the test of constitutional reasonableness. ${ }^{298}$ Each case would have to be decided on its own facts and circumstances. Alluding again to the supervisory-constitutional distinction, he concluded that the states were free to develop "workable rules" governing arrests and searches and seizure; this would be subject only to the same underlying limitations of the fourth-fourteenth amendment. ${ }^{299}$ Hence a fundamental uniformity was recognized subject only to reasonable variations growing out of "investigative and enforcement techniques." ${ }^{300} \mathrm{He}$ then proceeded to apply this underlying federal standard to the California practice illustrated by the facts before him.

Having affirmed the finding of probable cause in Part II, Mr. Justice Clark moved in Part III to a discussion of the method of entry. He began by noting that the lawfulness of arrests for a federal offense was a question of state law subject only to the Constitution. Here he cited Miller, Di Re, and Johnson. For Mr. Justice Clark, a fortiori the lawfulness of an arrest by state officers for state offenses was to be determined by California law, specifically section 844 and the judicial gloss of Maddox. Under the holding of Part I, the California rule had only to meet the fundamental criteria of reasonableness imposed by the Constitution to pass muster. He held that it did.

Assuming that entry by key was the legal equivalent of "breaking," 301 he recognized the reasonableness and lawful character of such a breaking in certain circumstances. After noting this, he began a series of contrasts between Miller, section 3109, and the California rule, arguing by way of analogy. He referred to Miller as having been decided as a question of "the law of the District of Columbia," which was, he said, by a court-accepted concession in Miller, "substantially identical" to the general federal rule for search warrants under section 3109. He then noted that no exigent circumstance exception had been argued or discussed at length in Miller, and the Court had merely cited the Maddox decision "without disapproval." ${ }^{302}$ By contrast, under Maddox, the California rule "clearly" included "an exception to the notice requirement" under "exigent circumstances." 303

During this preliminary discussion, prior to his actual holding, Mr. Justice Clark made some obiter observations pregnant for the

298374 U.S. at 32.

299 Id. at 34.

300 Ibid.

301 Here he referred to Keiningham v. United States, 287 F.2d 126, 130 (D.C.

Cir. 1960).

302374 U.S. at 40.

303 Id. at 39. 
administration of federal criminal law. Although Mr. Justice Clark had previously described Miller as District of Columbia law, making a further contrast between Miller, section 3109, and the California rule, he observed that Miller was "inapposite for state prosecutions, where admissibility is governed by constitutional standards" "insofar as [it involved a] violation of a federal statute . . . ." 304 To the degree that Mr. Justice Clark was echoing his earlier-mentioned distinction between supervisory power and constitutional suppression, what he said here is clear enough. Yet by referring to Miller as involving the exclusion of evidence under the aegis of a "federal statute," he contradicted his prior observation that Miller was District of Columbia law. The difference is crucial when federal arrests occur outside the District of Columbia. Are federal arrests in California when an entry without announcement occurs, for example, to be governed by section 844 with the gloss of Maddox, or section 3109 with the gloss of Miller? It is hardly necessary to point out that Maddox and Miller evinced an almost absolute polarity in judicial attitudes toward the question of proper announcement.

As if the confusion on this point was not already hopeless, Mr. Justice Clark proceeded in a footnote ${ }^{305}$ to add to what he himself had termed a "Chinese puzzle." He observed that in Wong Sun v. United States" 308 "the Court held that Federal Officers had not complied with $\S 3109$ in executing an arrest." ${ }^{307}$ This is what he had accused the majority of doing in his dissent in Wong Sun. ${ }^{308}$ The majority opinion, moreover, is susceptible to this construction. Yet it is hard to see how a federal statute dealing with search warrants can apply to an arrest without a warrant made in California. Since Justices Harlan, Stewart, and White concurred in the Wong Sun dissent and Mr. Justice Black concurs in this Ker observation on Wong Sun, does it mean that there is now a five man majority for the proposition that section 3109 controls the manner of entry in federal arrests? Is it ever profitable to speculate on points such as this? It is enough, perhaps, to refer to them merely to illustrate the confused state of the law.

Coming back to the analysis of Mr. Justice Clark's argument, he proceeded, following the Miller and section 3109 allusions, to finding "uniquely present" the "justification for the officers' failure to give

304 Ibid.

$305 I d$. at 40 n.11.

306371 U.S. 471 (1963) (dissenting opinion).

307374 U.S. at 40 n.11.

308 See text accompanying note 269 supra. On the "clarifying" function of dissents see Jackson, The Supreme Court in the AMerican System of Government 18-19 (1955). 
notice." 309 He found the destruction of evidence rationale of Maddox reasonable and then isolated two factors which made it applicable: the officers knew Ker was in possession of narcotics which could be easily and quickly destroyed, and Ker's furtive conduct in eluding them shortly before the arrest warranted them in thinking he might be expecting the police. ${ }^{310}$ These two factors taken with the officers' past experience with attempts to destroy evidence justified the unannounced entry which Mr. Justice Clark and his brethren felt was not unreasonable under "the standards of the Fourth Amendment as applied to the states through the Fourteenth Amendment." 311

As was noted above, Mr. Justice Harlan concurred only in the result. He expressed his opinion that the abandonment of the more "flexible concept" of due process was "uncalled for and unwise." 312 It was uncalled for because the states had been showing increasing "concern" with improving their own criminal procedures and unwise because of the "differing" problem faced on the state level and the "atmosphere of uncertainty" which would be created in view of the lack of "predictability" of the "Court's decisions in the realm of search and seizure." ${ }^{13} \mathrm{He}$ disapproved, in short, of the whole "constitutional adventure." 314

Mr. Justice Brennan began his dissent by setting out the three circumstances which would, in his opinion, justify an unannounced entry. For him, and his codissenters, all other unannounced entries, with or without a warrant, would violate the fourth amendment.

The first exception arises out of the situation "where the persons within already know of the officers' authority and purpose." ${ }^{15}$ Here it is appropriate to ask if "already know" differs from the "virtual certainty" standard set out in Miller. Does the exception depend on the objective fact or the situation as it appeared to the officers tested by the "virtual certainty" rule? Mr. Justice Brennan does not enlighten us on this point.

The second exception deals with the situation where "the officers are justified in the belief that persons within are in imminent peril of

309374 U.S. at 40.

310 During the investigation which preceded the arrest, the officers had observed one Murphy and Ker apparently engaged in a sale of narcotics. Later, while following Ker's car, the officers lost Ker when he made a U-turn in the middle of the road and drove in the opposite direction. It was following this occurrence that the officers went to Ker's apartment to make the arrest. Id. at 27.

$311 \mathrm{Id}$. at 41 .

312 Id. at 45 (concurring opinion).

313 Ibid.

314 Id. at 46.

$315 \mathrm{Id}$. at 47 (dissenting opinion). 
bodily harm." 316 Would Mr. Justice Brennan seriously limit the bodily peril exception to danger to persons within? What of the potential danger to the officers themselves? This is usually thought sufficient. ${ }^{317}$ Later on, he expresses concern with possible danger to officers, citing Mr. Justice Jackson's language in McDonald about the "fearful householder" shooting down by mistake an entering officer. ${ }^{318}$ Of course, Mr. Justice Brennan does not say "only within," but the use of "persons within" is a change in the formula he employed in Miller. There he said "they or someone within." ${ }^{18}$ At any rate, the language is unfortunately ambiguous.

The third exception deals with the situation where the people within engage "in activity which justified the officers in the belief that an escape or the destruction of evidence is being attempted" after they are "made aware of the presence of someone outside." $320 \mathrm{Mr}$. Justice Brennan, however, cuts the heart out of this exception later in his dissent. Here he speaks of exceptions to the rule of announcement. Later he observes that "in the absence of a showing of awareness by the occupants of the officers' presence and purpose, 'loud noises' or 'running' within would amount, ordinarily, at least, only to ambiguous conduct. [This could not] . . . form the basis for a belief . . . that . . . the destruction of evidence is being attempted." 321 Hence it would appear that an announcement, or a substitute which would fit under the first noted exception, is a prerequisite to the application of this exception. Is it then really an exception?

Having summarized by way of introduction his whole dissent, $\mathrm{Mr}$. Justice Brennan then began a three-part detailed analysis of his position, accompanied by the review of numerous English and early American cases. The parts may be roughly divided into the statement of the rule; the existence of exceptions; and the application of a possible exception to the case before him.

His first citation in establishing the existence of the rule was the broad dictum from Semayne's Case. He also added references to such early text writers as Hale, Hawkins, and Foster. He does not mention such interesting facts about the earlier commentators as Foster's statement that the castle rule, when applied to arrest on legal process,

316 Ibid.

317 Compare Read v. Case, 4 Conn. 166 (1822), with People v. Potter, 144 Cal. App. 2d 258 (Dist. Ct. App. 1956).

318374 U.S. at 58 n.12 (dissenting opinion), quoting 335 U.S. 451, 460-61 (1948) (concurring opinion).

319357 U.S. at 309.

320374 U.S. at 47 (dissenting opinion).

321 Id. at 57. 
"hath been carried as far as the true principle of political justice will warrant; perhaps beyond what is the scale of sound reason and good policies they will warrant." ${ }^{\mathbf{2} 22} \mathrm{He}$ also fails to point out that they disagreed about the application of the rule in certain circumstances and that they relied in formulating the rule primarily on the untested dictum of Semayne's Case-a noncriminal case.

Next he cites Curtis' Case ${ }^{323}$ as an "emphatic confirmation" just "35 years before the ratification of the Bill of Rights" 324 of the broad rule he is advocating. The fact of the matter is that Curtis' Case cuts against his position as much as it supports him. An announcement had been made, so the issue of exceptions was not before the court and the court had found sufficient to negate a defense to murder a nontechnical form of announcement. As such, they were not dealing with the naked right of the officer to enter, but the right of the householder to defend himself. This is not the place for an extended discussion of the question, but conceivably different forms of announcement, or the lack thereof, might warrant different results, depending on the context in which the right in question is asserted. ${ }^{325}$ Civil damages, defense to homicide, and the validity of the execution of civil or criminal process, all involve varying considerations. For this reason, it really is not cricket to cite such cases as "emphatic confirmations" of anything except their narrow holdings.

The difficulty in relying on inapposite cases is also brought out by Mr. Justice Brennan's use of Launock v. Browen. ${ }^{326}$ He quotes from Chief Judge Abbott's opinion, but leaves out the Judge's language which indicates the application of the announcement rule was, as late as 1819 , unsettled judicially in felony criminal cases. He could have avoided quoting the Chief Judge out of context if he had only cited Mr. Justice Bayley's comments. ${ }^{327}$

Mr. Justice Brennan then makes the patently unsupportable statement that the actually unsettled and untested rule of announcement, which he terms "firmly established," was "undoubtedly included" in "the individual freedom carried into the Fourth Amendment." $328 \mathrm{He}$ indicates further that "both the federal and state courts have recognized . . . that the requirement is of the essence of the substantive

322 Foster, Crown Law 319-20 (3d ed. 1792).

323 Fost. 135, 168 Eng. Rep. 67 (K.B. 1756).

324374 U.S. at 48 (dissenting opinion).

325 See, e.g., Kelly v. State, 80 Tex. Crim. 257, 190 S.W. 169 (1916); State v. Williams, 49 Utah 320, 163 Pac. 1104 (1917).

3262 Barn. \& Ald. 592, 106 Eng. Rep. 482 (K.B. 1819).

327 See note 35 supra.

328374 U.S. at 49 (dissenting opinion). 
protections which safeguard individual liberty." 329 Here he cites the "no division of opinion" language from Accarino ${ }^{330}$ and a long quote from the Massachusetts case of Barnard $v$. Bartlett. ${ }^{331} \mathrm{He}$ does not mention that the Massachusetts Supreme Court had, in Commonwealth v. Reynolds, ${ }^{332}$ also recognized that most of the law on announcement had been framed, not in terms of the right to enter under certain circumstances without announcement, but in terms of the unquestioned right to enter in every case in which an announcement had taken place. The criticism of Accarino need not be repeated here. ${ }^{33}$ Likewise he fails to comment on the observations of the Court of Appeals of Kentucky on the right not to announce when he cites Hawkins $v$. Commonwealth ${ }^{334}$ and $M c C a s i n$ v. McCord ${ }^{335}$ as examples of "frontier states" enforcing the rule. 336 The quoted statement from $M c C$ Cord is pure dictum. He further fails to note the many federal and state cases, collected above, which could certainly be cited against him. ${ }^{337}$

In the closing paragraphs of Part I, Mr. Justice Brennan gets to the core of the question: the policy consideration which may be offered to support the rule. He refers to the early colonial experience with writs of assistance. He frankly notes that "the problem of entry under a general warrant . . . [is] not . . . exactly that of unannounced intrusion" yet he observes that "the two practices clearly" invite "common abuses." 338 For Mr. Justice Brennan, "similar, if not the same, dangers to individual liberty are involved." ${ }^{339}$ He notes general warrants required "some form of notice," and the writs could only be served "during daylight hours." 340 Then he cites Gouled v. United States "341 for the proposition that a "lawful entry" is "the indispensable predicate of a reasonable search" ${ }^{342}$ and he states that he would put "rigid restrictions upon unanounced entries." 343

329 Ibid.

330179 F.2d 456, 462 (D.C. Cir. 1949).

33164 Mass. (10 Cush.) 501, 502-03 (1852).

332120 Mass. 190, 196 (1876).

333 See text accompanying note 87 supra.

$33453 \mathrm{Ky} .395,397$ (1854).

335116 Tenn. 690, 94 S.W. 79 (1906).

336374 U.S. at 50 (dissenting opinion).

337 All of this, of course, is not to say that the rule does not exist, or ought not to exist. These comments are made here merely to point out that the rule advocated by Mr. Justice Brennan is not compelled by history.

338374 U.S. at 51 (dissenting opinion).

339 Id. at 52.

340 Ibid.

341255 U.S. 298 (1921).

342374 U.S. at 53 (dissenting opinion).

343 Ibid. 
It is indeed unfortunate that Mr. Justice Brennan was not more explicit in his discussion of the policy behind the rule. He never spelled out the "common" or "similar" abuses to which he referred. Nor does he make clear the crucial distinction between the right to enter and the manner of entry. Such cases as Gouled are, in fact, only intelligible when it is pointed out that an entry reithout probable cause, albeit by stealth, was made. Without the right to enter, it is immaterial that the entry is by stealth rather than by force, since the consent given does not fairly extend to the individuals' hidden purpose of search. Gouled, therefore, says nothing about the situation in which the entry is by right and the only question is how it shall be effected. His use of the phrase "unlawful entry" is, therefore, ambiguous; it can refer to "without right" or in an "improper manner." The issues in the general warrants and writs situations are similarly not on point. If unannounced entry ought to be restricted in any fashion, Mr. Justice Brennan fails to tell us why.

The closing paragraph of Part $I$ is worth noting in detail since it comments on Miller. Mr. Justice Brennan, of all people, is probably right when he observes that the Court in Miller "drew upon [an] analogy to a federal statute" in suppressing the evidence. ${ }^{344}$ Of course, if it was only an analogy to, and not the statute itself, which the Court used, then section 3109 has no application, as such, to arrests. Mr. Justice Brennan also makes the valid point that it would have been improper to decide Miller on a constitutional basis since a nonconstitutional ground existed.

Part II is begun with a confession by Mr. Justice Brennan that he could not find any English cases which recognized an exception to the rule. ${ }^{35}$ For Mr. Justice Brennan, therefore, the exceptions to the rule were of American origin and were always "rigidly and narrowly confined." 346 And, more importantly, he would limit all exceptions, save one, to those which would meet a test of knowledge or awareness of the officers' presence. The exception is "where the officers are justified in the belief that someone within is in immediate danger of bodily harm." 347

344 Ibid.

345 However, in Aga Kurboolie Mahomed v. The Queen, 4 Moore P.C. 239, 247, 13 Eng. Rep. 293, 296 (1843), Lord Campbell recognized, in upholding a forcible reentry without an announcement after a prior peaceful entry to make a civil arrest, that the "law in its wisdom only requires this ceremony [of announcement] to be observed when it possibly may be attended with some advantage, and may render the breaking open of the outer door unnecessary."

346374 U.S. at 54 (dissenting opinion).

347 Id. at 55 . 
Here Mr. Justice Brennan uses his own opinion in Miller as the touchstone of his reasoning. For him, Miller rests on the simple proposition that the law does not require the performance of a "superfluous act"; ${ }^{348}$ you need not tell a person what he already knows. Two constitutional reasons based on certain practical considerations compel a rejection of any exception not involving this preexisting awareness: any other rule would involve an implied rejection of the presumption of innocence; and, absent awareness, all other circumstances which might indicate an entry should be made are "ambiguous." 349

Mr. Justice Brennan's use of the presumption of innocence comes perilously close to the classic fallacy of treating the presumption as evidence per se rather than merely as a statement of where the burden of proof lies. ${ }^{350}$ For the Justice, a failure to knock or announce can only rest on the "automatic assumption" that the suspect within will resist arrest, attempt escape, or destroy evidence. ${ }^{351} \mathrm{He}$ observed that another "assumption" is also necessarily involved: that a suspect to whom an identification of official character is made will further violate the law. Not every suspect is in fact guilty nor will every guilty suspect resist arrest, attempt to escape, or destroy evidence. ${ }^{\mathbf{3 5 2}}$

This line of reasoning is logically impeccable only if the basis for the exception is, in fact, merely an assumption. On the other hand, if it constitutes a judgment of fact based on empirical experience, it cannot be attacked by theory but only by a refutation of the inference drawn, or a challenge of the experience itself. The presumption of innocence here is relevant only to the degree that it says that the burden of proof for justifying a course of action other than announcement should lie on the officer. It says nothing about the quantum or character of evidence which might warrant such action. Once evidence is introduced, moreover, the presumption ought to end, assuming the quantum of evidence required by sound social policy is met. It is instructive to point out that the Constitution itself only requires a "probability" not a "certainty," prior to arrest and search, and so, therefore, talk about the problem from the point of view of objective hindsight is not really apposite.

Mr. Justice Brennan's second point about ambiguity, in part, begs the question. Since the actual equation in an entry situation includes

348 Ibid.

349 Id. at $56-57$.

350 See United States v. Nimerick, 118 F.2d 464, 468 (2d Cir. 1941). See generally 9 WIGMORE, EVIDENCE \$2511, at 406-12 (3d ed. 1940). Compare Coffin v. United States, 156 U..S. 432 (1895), with Agnew v. United States, 165 U.S. 36, 51 (1897), and Holt v. United States, 218 U.S. 245 (1910).

351374 U.S. at 56 (dissenting opinion).

352 Ibid. 
a probability of guilt, action which in the abstract might be ambiguous takes on a different color, particularly so when viewed by the trained and experienced police officer.

Mr. Justice Brennan also presents two practical hazards; some innocent citizens will unquestionably have their homes broken into without announcement, and announcement "serves to minimize the hazards of the officers' dangerous calling." ${ }^{353}$ No argument can be presented which will even mitigate the force of Mr. Justice Brennan's first point. It must be admitted that innocent citizens will suffer. The question, however, is not how to eliminate the evil, but how to balance that evil against the alternative evil. Likewise, it is certainly a praiseworthy objective to minimize the hazards of the officers' calling. One only wishes, however, that there was a firmer basis for the evaluation of alternatives beyond mere speculation. The case law indicates that the officer is shot sometimes when he announces and sometimes when he does not. ${ }^{354}$ Since we are dealing with a situation in which the occupant is "probably" an outlaw, and the officer is presumptively innocent, it would be desirable to have a flexible rule which, under appropriate circumstances, would permit the officer to assess the situation himself and make his own judgment in the first instance, rather than have a rigid rule formulated in the law library. ${ }^{355}$ Holmes' point about the "happy phrase" uttered "from a protected cloister" is relevant here. ${ }^{356}$

Mr. Justice Brennan ends Part II with two final observations. $\mathrm{He}$ rejects the contention that the rule of announcement might "create serious obstacles to effective law enforcement." ${ }^{357}$ He says that the federal officers under the Miller rule have suffered "no discernible impairment of their ability to make effective arrests and obtain important narcotics convictions." ${ }^{358} \mathrm{He}$ also finds unconvincing suggestions that varying law enforcement problems may necessitate varying law enforcement standards. On the second point, it is sufficient here that

353374 U.S. at 58 (dissenting opinion).

354 Compare Kelly v. State, 80 Tex. Crim. 257, 190 S.W. 169 (1916) (shot without announcement), with State v. Williams, 49 Ưtah 320, 163 Pac. 1104 (1917) (shot with announcement).

355 For example, when a situation of possible peril was involved, an officer might decide that it would be wise to announce himself yet not wait for a refusal. The announcement would serve to dispel any possibility of mistake and the immediate entry would give the officer the advantage of being on the offense. A rigid library rule might, on the other hand, see the situation solely in terms of alternativesannouncement or no announcement.

356 Holmes, Sperches 73 (1934).

357374 U.S. at 58 (dissenting opinion).

$358 I d$. at 59. 
reference be made to the argument of the Attorney General of California. ${ }^{359}$

As to the first point, again one wishes statistics were available. Mr. Justice Brennan cites none. He does not refer to the opinion of a federal law enforcement agency or a civil liberties organization. ${ }^{\mathbf{3} 0}$ Miller is, of course, a comparatively young rule and there is considerable doubt as to the scope of its application. It is apparent, however, from a few reported post-Miller cases reviewed above, that entry questions are being raised in most narcotic and gambling cases being prosecuted. $^{301}$ It has resulted in the suppression of evidence in some situations in which the application of the rule could only be termed ludicrous. Still, the safest estimation of Miller is that it is too soon to say that federal law enforcement is crippled; yet the future is not bright.

In Part III, Mr. Justice Brennan finally turned his attention to the case at hand. He approached Mr. Justice Clark's opinion under two headings: the rule of "fresh pursuit," and the exception founded on the possibility of the destruction of evidence. ${ }^{362}$ He noted Mr. Justice Clark's observation on Ker's furtive conduct prior to arrest and criticized it as "mere conjecture." 363 To the degree that Mr. Justice Clark sought to invoke the fresh pursuit rule, and it is not clear that he did-Mr. Justice Brennan himself says "apparently seeks to invoke" ${ }^{364}$-there is much merit in this observation. There was little evidence showing the kind of awareness that ought, as Mr. Justice Brennan rightly thinks, to be a prerequisite to the application of the exception. The evidence available indicated, moreover, that $\mathrm{Ker}$ had lost the police, not that they were still in active pursuit. ${ }^{365}$ Yet $\mathrm{Mr}$. Justice Clark is surely also right when he criticizes Mr. Justice Brennan for using the information that developed after the officers' entry. ${ }^{366}$ If postentry information is relevant it ought to cut both ways, and this is a principle which Mr. Justice Brennan would be the last person to adopt. ${ }^{367}$

359 Brief for Respondent, pp. 12-17.

360 One would suppose that these would be the two most informed-and balanced - groups to ask. Presumably the testimony of the criminal class itself would be too biased.

361 Where the suppression takes place on a pretrial motion and no opinion is written, of course, that usually ends the matter. Di Bella v. United States, 369 U.S. 121 (1962). It is only by chance that you will run across a relevant unreported case. 362374 U.S. at 60-61 (dissenting opinion).

363 Ibid.

364 Id. at 60.

365 See note 310 supra.

366374 U.S. at $40-41$ n.12. Mr. Justice Clark notes the familiar rule illustrated by Johnson v. United States, 333 U.S. 10, 17 (1948). It is the evidence prior to entry or arrest which counts.

$367 \mathrm{He}$ used the rule himself in Miller, 357 U.S. at 313. 
As Mr. Justice Brennan observes, the Clark opinion "invokes chiefly" ${ }^{368}$ the destruction of evidence exception, and it is on this point that the dissent makes its most telling criticisms. For the minority, the application of the exception would depend on an interpretation placed on "activity within the apartment." ${ }^{\text {as }}$ The Clark opinion, on the other hand, apparently is willing to accept, he says, the "general experience" of the officers in narcotic cases as a sufficient showing of possibility of evidence destruction to warrant the application of the exception. $^{370} \mathrm{Mr}$. Justice Brennan correctly observes that logically applied such an exception presents a real "hazard" that the exceptions "will devour the rule." ${ }^{371}$ Here perhaps the only thing that can be said for the Court's position is that it will probably not be logically applied. Restricted to narcotics and similar cases, it does make some sense. Yet Mr. Justice Brennan's position likewise ought not be logically applied. Assume, for example, that reliable information, in addition to coming up to the standard of probable cause to search, also indicated that gambling records, properly seizable under search warrant, were kept on flash paper and the door to the house in question was bolted so that the occupants would have a chance to ignite the records prior to entry. Should the officers in executing a search warrant in such a situation give the occupants a chance to take "activity within" after an announcement or a knocking prior to forcing entry? Only a person who elevates logic over experience, it is suggested, would say that they should.

Criticizing the Clark opinion, Mr. Justice Brennan also refers to "general experience" as being a "subjective judgment" inadmissible when the Constitution has always thought necessary an "objective inquiry." 372 Not to quibble with words, a judgment based on general experience can be "objective." $\mathrm{He}$ does make himself somewhat clearer, however, when he later indicates that "objective" means to him "whether circumstances exist in the particular case." 373 Still, it would seem that there is no absolute prohibition from making judgments in classes of cases based, not on the particular situation which will be, or is being, encountered, but rather on the kind of case it will be.

A reasonable judgment based on past experience with similar cases is just as valid a source of "probability," and that is all we are really

368374 U.S. at 61 (dissenting opinion).

369 Ibid.

$370 I d$. at 63 .

371 Id. at 61 .

372 Id. at 63.

373 Ibid. (Emphasis deleted.) 
dealing with, as a reasonable judgment based on facts actually being experienced at the time. The difference is that between general and particular experience and not between objective and subjective judgment. The judgment may in either case be subjective or objective. It would certainly be novel to assert that the Constitution somehow limits legally cognizable judgments to those based solely on particular experience.

Mr. Justice Brennan's parting comment bids warning to federal officers. Like Mr. Justice Clark, he too distinguishes between constitutional and supervisory power suppression. Hence it may be that he might impose an even "higher" standard on federal than on state officers. Logically and legally, the Court has no power to impose a supervisory sanction on the states. They would, therefore, have to meet only the federal minimum. If a "higher" standard is to be imposed on state officers it would have to emanate from the states themselves. Federal officers are not so fortunate. Again, apparently the future is dark for Federal officers.

\section{F. Conclusions}

Several tentative conclusions may be drawn from Ker:

(1) The decision indicates that the rule of announcement is of constitutional dimension.

(2) The rule is, however, subject to an exception based on the reasonable possibility that evidence may be destroyed which would otherwise be subject to lawful seizure.

(3) The source of authority that must be consulted in the first instance when federal arrests occur outside the District of Columbia remains unclear.

(4) Whether an evidence-destruction exception will be recognized when federal law enforcement officers are involved also remains unclear.

\section{Conclusion}

Overall criticism and evaluation of the development of the rule of announcement in Miller and Ker must begin by placing the rule in the larger context of the suppression sanction. Debate over the exclusionary rule has raged intermittently for forty years. The literature this debate has produced is, as Professor Allen notes, "more remark- 
able for its volume than its cogency." ${ }^{374}$ It would be foolish to attempt to review the whole question here. For our limited purposes one observation should be sufficient: the exclusionary rule makes senseand it does make sense-only to the degree that it offers a means of deterring unlawful police action through compelling respect for law "by removing the incentive to disregard it." ${ }^{375}$ Loose language to the contrary will not withstand "close analysis." 376

Yet the concept of deterrence implies an existing rule of action clearly understood. It is simply question-begging to speak of vindicating a right which cannot be meaningfully said to have preexisted the proceedings in which the vindication is to take place. We put up with this sort of thing in the judicial process generally since the creation of new rights is usually the exception and not the rule. The law, after all, must grow; it cannot remain static. Courts legislate, it is said, but only "interstitially." ${ }^{377}$ The development of the rule of announcement, however, is but a conspicuous illustration of a broader problem. For the chief difficulty with the law of arrest, search, and seizure is that its predominant feature, despite its venerable heritage, is that of change; it has little or no stability. ${ }^{378}$ It is ludicrous, therefore, to speak of meaningful deterrence when there is no preexisting ascertainable standard of conduct. ${ }^{379}$ Constitutional due process otherwise generally requires such a standard. ${ }^{380}$ How can our Constitution require the rules by which we incarcerate members of our society, who supposedly undermine its well being, to be ascertainable, yet permit the rules by

374 Allen, Federalism and the Fourth Amendment: A Requiem for Wolf, in 1961 Supreme Court Review 33 (Kurland ed.).

375 Elkins v. United States, 364 U.S. 206, 217 (1960).

376 Barrett, Exclusion of Evidence Obtained by Illegal Searches-A Comment on People v. Cahan, 43 Calif. L. Rev. 565, 580 (1955).

377 Southern Pac. Co. v. Jensen, 244 U.S. 205, 221 (1917) (dissenting opinion of Holmes, J.).

378 The Court itself has attested to the uncertainty in this area. A few of the Justices' remarks are collected in Note, 28 U. CHI. L. REv. 664, 665 n.9 (1961). In United States v. Rabinowitz, 339 U.S. 56, 86 (1950) (dissenting opinion of Frankfurter, J.), for example, it is said that "changes in the Court's composition and the contingencies in the choice of successors" have often been the key to decisions.

${ }^{379}$ To be sure, a vague rule may in fact deter. However, when the police officer out of caution reads the rule conservatively, the deterrence effected will be of both permissible and impermissible conduct. On the other hand, when the officer resolves doubts in favor of action, the vague rule will fail to deter illegal action which a clearer rule might have eliminated. Either way, the interests of both society and the individual, which in the long run are the same, will suffer.

The vague rule also poses an even more serious threat to the administration of justice. The police officer who does not know how to follow the law experiences a frustration of which the ultimate fruit benefits no one: the result will be either no action, out of a "what's the use" attitude; corruption, out of a "I might as well get something out of it" attitude; or illegal, extrajudicial law enforcement, out of a "if I can't get my job done with the help of the courts, I'll get it done without them" attitude. In the final analysis, such a rule tends to break down law enforcement and creates a situation far worse than that which existed prior to its formulation.

380 See Lanzetta v. New Jersey, 306 U.S. 451 (1939). 
which we discipline law enforcement officers, who supposedly promote its well being, to be chaotic?

Once the Supreme Court had agreed to hear the Miller appeal, it is difficult to see why the majority decided the case on such a narrow ground as the law of the place where the arrest occurred. By holding that the law of the District of Columbia controlled the legality of the entry, the majority placed federal arrests by federal officers in jurisdictions other than the District of Columbia under anything but an ascertainable or, for that matter, uniform standard. Further, it is unfortunate that the majority opinion only referred to the basis of the decision in the context of what subsequent cases have indicated was an ambiguous discussion of a federal statute of general application. The execution of search warrants is to be governed by the federal statute. Arrests, however, are to be governed by reference to state law, that is, if the judge hearing the motion to suppress correctly reads the Miller opinion. When he does not, or he is led astray by the argument of an unschooled Assistant United States Attorney or a skilled defense attorney, the picture only becomes more complicated. Most states have no clearly articulated body of precedent in the area of announcement and entry. Almost every arrest situation has become, therefore, a case of first impression. Nothing the Court said in Wong Sun can properly be construed as dispelling this unfortunate ambiguity. Likewise $K e r$ has only served to compound the problem. Putting aside Ker's internal inconsistencies, it seems clear that if state law still governs the question of arrest announcement (and this itself is not clear), it is subject to the limitations of the fourth amendment. But observe what result this incidentally produces. Federal attorneys must now argue what state law is, and then justify it under a federal standard, all without the participation of responsible state officials or definite guidelines. What does this do to the concept of a healthy federalism? Under these circumstances, the safest course of action for the conscientious federal officer to follow is to impose on himself the strictest possible standard, thus eliminating the possibility of pursuing a flexible course of conduct tailored to meet each new situation. Even then he can expect the result will often be that he will not be informed until after the entry that the particular course of conduct chosen was "illegal." The situation in which search rather than arrest is concerned has fared a little better, but only because there is an existing federal statute, which, of course, has itself been inconsistently interpreted. The fundamental point, however, remains valid. Under the present status of the law, the interest each of us has in lawful and effective law enforcement is today denied the simple due process requirement of an ascertainable 
standard of conduct. The point Mr. Justice Brandeis made in another context should be made here: it is sometimes as "important that the applicable rule of law be settled than that it be settled right." 381

In the final analysis, the aspect of Miller and $K e r$ subject to the strongest criticism is the disregard of what Mr. Justice Frankfurter in his dissent in Rabinowitz termed "historical material." ${ }^{382}$ At common law, the rule of announcement was designed to avoid unnecessary violence in the execution of civil process. The castle maxim, historically understood, never properly applied to the execution of criminal process, and the application of the rule of announcement was until very recently untested dicta. The rule the Court in Miller and Ker speaks about, however, is ambiguously offered as a protection not against unnecessary violence but of some undefined aspect of the "right of privacy." The distinction between privacy and violence is not just a question of theory. As Mr. Justice Frankfurter also observed in Rabinowritz, "where one comes out on a case depends on where one goes in." 383

A conclusion is, of course, not an appropriate time to attempt to define the "right of privacy." For what Acton said of liberty, can be said of privacy: It is "an idea of which there are two hundred definitions . . . ." 384 It is, moreover, an idea "better suited to literary than legal analysis." ${ }^{885}$ It will be sufficient here, however, if we use Mr. Justice Brandeis' own definition. The right of privacy may be said to be the right "to be let alone." 386

We may analyze the rule of announcement, then, in terms of two quite different concepts. From the point of view of a "right to be let alone," announcement is seen to be a condition precedent to the existence of the opposite "right to enter," which, when in existence, takes priority over the former "right to be let alone." The right to enter to arrest or search, then, does not mature until notice is given or an adequate substitute is present and the occupant consents. Notice the emphasis on the occupant's consent. When he explicitly or implicitly refuses to permit entry, such entry becomes lawful not by consent but by operation of law. On the other hand, from the point of view of force, announcement is seen as an option given under ordinary circumstances to an occupant to avoid the use of physical violence.

381 Burnet v. Coronado Oil \& Gas Co., 285 U.S. 393, 406 (1932) (dissenting opinion of Brandeis, J.).

382339 U.S. 56, 69 (1950) (dissenting opinion of Frankfurter, J.).

383 Ibid.

384 Acton, EsSays on FreEdom ANd Power 36 (Meridian ed. 1960).

385 Beany, The Constitutional Right to Privacy in the Supreme Court, in 1962 Supreme Court Review 214 (Kurland ed.).

386 Brandeis \& Warren, The Right to Privacy, 4 Harv. L. Rev. 193, 205 (1890). 
When the occupant refuses to permit entry, he and not the law may be said to be the cause of the destruction of the public peace. Entry in either situation under the force analysis is by operation of law and not by consent. Here the question of consent is irrelevant.

The pragmatic difference between these two theoretical approaches is brought sharply to the fore by the entry-by-trick-absent-force situation. If the interest to be protected is the occupant's initial ${ }^{887}$ right voluntarily to relinquish his right to be let alone, then the dissenters in Jones $v$. United States ${ }^{388}$ have the best of the argument, and Leahy v. United States ${ }^{380}$ was wrongly decided. Leahy, of course, upheld outright misrepresentation; Jones upheld trick by implication. It is difficult to see how the distinction between the two is meaningful. The entries in both cases were ultimately by ruse. Meaningful consent played no part. But if it was unnecessary force which was at issue, then it is hard to argue with the thrust of Judge Orr's opinion in Leahy, and such cases as Gouled v. United States ${ }^{390}$ are quickly placed in perspective. They involve ultimately questions going not to the manner of entry but the right to enter. When the right to enter exists, the manner of entry may be viewed in a different light. Ultimately, this is the burden of Judge Orr's opinion. So Justices Traynor and Weintraub likewise make clear in Maddox and Smith.

Not having analyzed precisely what is involved, the Court in Miller and $\mathrm{Ker}$ also cannot be said to have properly balanced the competing interests intertwined in the announcement situation. For, as the late Judge Learned Hand put it, when you are dealing with such admonitions as "unreasonable searches" there appears to be "no escape in each situation from balancing the conflicting interests at stake with as detached a temper as we can achieve." ${ }^{391}$ Balancing, moreover, is only part of the problem. As Professor Fried persuasively argues, the formulation of the interests is just as important; it must always be asked "who" is asserting "what." ${ }^{392}$

387 It is difficult to see how the right to consent to entry after announcement can be considered more than an initial right. For immediately upon a refusal, all agree the question of consent becomes moot. How meaningful this concept of consent is, moreover, is also open to question. Mr. Justice Rutledge, in dissent in Davis v. United States, 328 U.S. 582, 623 (1946), aptly observes:

But the search followed on consent given in the reasonable belief that it was necessary to avoid the breaking and entry. I think it was therefore in no better case legally than if in fact the breaking and forceable entry had occurred.

388304 F.2d 381, 385-87 (D.C. Cir. 1962), cert. denied, 371 U.S. 851 (1963).

389272 F.2d 487 (9th Cir. 1960), cert. granted, 363 U.S. 810 (1960), dismissed by stipulation, 364 U.S. 945 (1961).

390255 U.S. 298 (1921).

391 Hand, The SpIRIT OF Liberty 179 (Dillard 3d ed. 1960).

392 See Fried, Two Concepts of Interest: Some Reflections on the Supreme Court's Balancing Test, 76 Harv. L. Rev. 755, 765-70 (1963). 
The rule of announcement has had its impact to date primarily in two sharply defined areas of law enforcement: narcotics and gambling. Each is but an aspect of the larger problem of organized crime. ${ }^{393}$ Any formulation of competing interests must then take this factor into account. The danger to our freedom presented by organized crime differs appreciably from the traditional danger that all crime poses. ${ }^{394}$ Little recognition, however, of this fact appears in the opinions of some of those participating in the law enforcement policy formulation of our judiciary. ${ }^{395}$ The majority in Miller, for example, saw fit to write into the law an apparently rigid rule of announcement. The absence of one word in announcement will call down upon all of the officer's work the Draconic sanction of suppression. Evidently no question of degree is involved. Such formalism is required, in spite of the obvious fact that any announcement fairly imparting that officers of the law seek admission inevitably carries with it some notice of the official character of the visit. Does it really make a difference whether the purpose is search or arrest? The probable cause which serves to underwrite the arrest or search will, moreover, usually carry with it the sound inference that the suspect or the occupant will be fully aware of the purpose of the entry.

The majority in Miller were, of course, not totally oblivious to the interests of sound law enforcement. They did recognize that in certain situations facts known to an officer might warrant noncompliance with what they articulated as the general rule. Yet the test that was formulated to govern the situation was "virtual certainty." One principle in the administration of law, however, is clear: there is no certitude. We impose the death penalty based only on the lack of "reasonable doubt." Search or arrest itself may be warranted by no

393 See generally Johnson, Organized Crime: Challenge to the American Legal System, 53 J. CrIM. L., C. \& P.S. 399 (1962), 54 J. CrIM. L., C. \& P.S. 1, 127 (1963); Hearings on Organized Crime and Illicit Traffic in Narcotics Before the Permanent Subcommittee on Investigations of the Senate Committee on Government Operations, 88th Cong., 1st Sess., pts. 1-2 (1963) (the so-called Valachi hearings). See also Symposinn-The Nature of Organized Crime and Problems in Law Enforcement, 38 Notre Dame Law. 627 (1963); Maas, Mafia: The Inside Story, The Saturday Evening Post, Aug. 10, 1963, p. 19.

394 See Tyler, An Interdisciplinary Attack on Organized Crime, 347 Annals, pp. 104, 109 (May 1963):

The present menace is real and frightening. In a society dedicated to the rights of the individuals, organized crime deprives many individuals of their inalienable rights, not by turning the overwhelming power of the state against a citizen, but by exercising the power of private government against the nonconformist. Strikers lose their right to picket; businessmen lose their right to buy, manufacture, and sell as they please and are forced to accept unwanted junior or senior partners; citizens lose the right to testify and others are forced to bear false witness. Even the right to honest and free elections is repeatedly jeopardized. opinion).

395 See, e.g., Lopez v. United States, 373 U.S. 427, 469 n.19 (1962) (dissenting 
more than the existence of "probable cause." It would appear, in fact, that the test for entry is higher than the test for search or arrest itself. If the majority is to be taken at its word there is no room for what Mr. Justice Rutledge termed in Brinegar $v$. United States, "the mistakes . . . of reasonable men." ${ }^{386}$ A test of "virtual certainty," it is submitted, is both "unrealistic and visionary." 397

What appears to be asserted here, to adopt Professor Fried's question, is the right in the usual gambling or narcotics case of the occupant of a house to have an opportunity to destroy evidence ${ }^{398}$ prior to seizure or obtain its suppression after seizure. Further, the right is asserted by a probable member of an organized conspiracy against the rights of us all. It is difficult to see how such a right can be recognized when so boldly stated. It is submitted, moreover, that when the assertion is stripped of rhetoric, this is precisely what is at issue.

It is true that the rigor of Miller must be contrasted with the flexibility of $\mathrm{Ker}$. Yet the promise of $\mathrm{Ker}$ seems limited to state law enforcement. The careful articulation of supervisory-constitutional suppression distinction does not leave the federal officer with the feeling that his efforts will be looked on through the same eyes. The "possibility that the evidence may be destroyed" exception will give state officers room to tailor their actions to the concrete situation. It appears doubtful, however, that federal officers will be accorded equal treatment.

On the other hand, whatever may be said for the need to suppress organized gambling and the narcotics traffic, there is still much to be said for a rule which would require a certain amount of civility on the part of the police officer before he enters the home of the ordinary citizen. ${ }^{309}$ Modern history has too often seen the police state's use and abuse of the knock on the door. Even if we go back to the enlightened community of Sodom, we find that the crowd before the house of Lot did not just break in. ${ }^{400}$ Yet, properly analyzed, it is submitted, the real issue in the announcement situation is solely the traditional question of force. Bringing in the amorphous concept of privacy merely confuses the problem. And, as long as the Court con-

396338 U.S. 160, 175 (1949).

397 Elkins v. United States, 364 U.S. 206, 222 (1960).

398 For example, it may take no less than thirty seconds to destroy all of the evidence of a wire-service headquarters. See McClellan, Gambling and Organized Crime, S. REP. No. 1310, 87th Cong., 2d Sess. 11 (1962).

399 See generally Simon, Philosophy of Democratic Governament 112-18 (1951).

400 See Genesis 19:4-5. The experience of the King of Jericho with the spies in Rahab's house is also illuminating. The walls would probably still have come tumbling down, yet had he ordered an unannounced entry, the spies at least would not have escaped. See Joshua 2:1-24. 
tinues to hold that state law governs the question, the inevitable tension between the privacy analysis and the force rationale outlined above will obtain.

So analyzed, the general rule properly becomes not that announcement should be made but that entry should be peaceful. Forcible entry becomes then the exception, and following the traditional analysis, the burden lies on him who would bring it into play to establish the necessity for it. ${ }^{401}$ The police officer ought, therefore, in the usual case to avoid force in obtaining entry by demanding it. Such a rule, however, would not be inflexible. When the police officer could show an acceptable reason for following another course of action the absence of announcement would be irrelevant. Such an acceptable reason, for example, would be the existence of a situation in which announcement would fairly defeat the overriding right of entry to arrest or search. Here the possibility of escape or the destruction of evidence comes to the fore. Likewise when the officer reasonably fears a demand would increase the likelihood of violence, it would be absurd to require it under a rationale founded on a desire to avoid such violence. It is not necessary to carry this tentative analysis out to greater length. Given an articulation of the real issues involved, the way most questions would be decided under such a rule is not difficult to predict.

But what of the present state of the law? Has the Court finally committed itself to a "privacy" analysis of announcement? ${ }^{402}$ Can we reasonably expect the Court to answer before long this and other questions posed by this analysis of the rule of announcement? The answer is fairly obvious. Of course we can. The real question is whether we want to permit the chaos in law enforcement to continue until the Court has had an opportunity to deal with it on a case by case basis. Congress too has a responsibility to deal with this confused situation. Appendix B contains a tentative draft of a statute which would deal with many of these problems. It is here offered not with the idea that it embodies the final word but the text of a solution which could serve as a starting point for a meaningful dialogue.

A final word is necessary. The burden of much that has been said here is adverse to the work of the Court in the area of criminal procedure. ${ }^{403}$ Lest anyone misunderstand, let it be made clear that

401 See McDonald v. United States, 335 U.S. 451, 456 (1948).

${ }^{402} \mathrm{Mr}$. Justice Clark's opinion in $\mathrm{Ker}$ speaks much more about "reasonableness" than "privacy." See 374 U.S. at 23.

403 The heart of the criticism here is that of Professor Freund:

What gives concern . . . is ... a tendency to make broad principles do service for specific problems that call for differentiation, a tendency toward overbroadness that is not an augury of enduring work and that misses the opportunity to use the litigation process for the refinement and adaptation 
this criticism grows out of a profound respect for the Court as an institution and the work of its individual members in this difficult area. The Justices receive by and large altogether too little help from the Bar that appears before them. They have likewise altogether too many hard problems to attempt to solve in too short a period of time by themselves. The work of forging the safeguards of liberty is too precious to entrust to just nine men. Too often the "dialogue" on these issues has existed solely between so-called "civil liberties" groups and representatives of "crime commissions." The need here is for objectivity. ${ }^{404}$ Congress, the Bar, and the schools must begin to turn their attention to these questions. ${ }^{405}$ It is in this spirit that this discussion of Miller and $K e r$ is offered and it is hoped that it will be received in this spirit.

of principle to meet the variety of concrete issues as they are presented in a lawsuit. . . . The law of the future is likely to be the law that earns its perdurance by solidity and strength of workmanship no less than by the appeal its results make to our ethical sense.

Freund, The Supreme Court of the United States 188 (Meridian ed. 1961).

$404 \mathrm{On}$ this point, Mr. Justice Cardozo should be remembered. In ThE NATURE OF THE JUDICIAL PROCESS 13 (1921), he aptly observes: "We may try to see things as objectively as we please. None the less, we can never see them with any eyes except our own."

405 To date there has been altogether too little serious attention devoted to these issues, particularly where problems posed by organized crime are concerned. Lumbard, Local and State Action Against Organized Crime, 347 Annals, pp. 82, 84 (May 1963), points this up: "Our foundations, universities, and other seats of intellectual stirring, including serious current literature and journalism, are almost barren of expressed concern for organized crime."

In some respects, it may be, perhaps, true that the facts of organized crime have "outflanked" our thinking about crime and criminal procedure in terms of the traditional common-law crimes and the procedures adopted for their prosecution and the protection of individual rights. The phrase, if not the idea, is Mr. Justice Brennan's in Lopez v. United States, 373 U.S. 427, 471 (1963) (dissenting opinion). 


\section{APPENDIX A}

\section{Rtght to Break Under Statute *}

\section{State}

Alabama
Alaska
Arizona
Arkansas
California
Colorado

Connecticut

Delaware

District of Columbia

Florida

Georgia

Hawaii

Idaho

Illinois

Indiana

Iowa

Kansas

Kentucky

Louisiana

Maine

Maryland

Massachusetts

Michigan

Minnesota

Mississippi

Missouri

Montana

Nebraska

Nevada

New Hampshire

New Jersey

New Mexico

New York

North Carolina

North Dakota

Ohio

Oklahoma

Oregon

Pennsylvania

Rhode Island

South Carolina

South Dakota

Tennessee

Texas

Utah

Vermont

Virginia

Washington

West Virginia

Wisconsin

Wyoming

United States

$\begin{array}{ll}\text { yes } & 34 \\ \text { no pro } & 18\end{array}$

Key :

yes ........provision present

no pro .....no provision present

yes(1) ...... provision limited to felony cases
Search Warrant

yes

yes

yes

no pro

yes

no pro

no pro

no pro

yes (narcotics \& liquor)

yes

yes

yes

yes

yes

no pro

yes

yes (liquor)

questionable

yes

no pro

no pro

no pro

no pro

no pro

yes (liquor)

yes

yes

yes

yes

no pro

no pro

no pro

yes

no pro

yes

yes

yes

yes

no pro

no pro

yes

yes

yes

yes

yes

no pro

no pro

no pro

no pro

no pro

yes

yes

$\begin{array}{lrlr}(1) & 8 & \text { yes } & 27 \\ \text { unlimited } & 22 & \text { no pro } & 21 \\ \text { no pro } & 21 & \text { questionable } & 1 \\ \text { questionable } & 1 & \text { limited } & 3\end{array}$

$\mathrm{w} / \mathrm{w}$...... with warrant

w/o ....... without warrant 
* 18 U.S.C. $\$ 3109$ (1958) (search); ALA. Code tit. 15, § 108 (1959) (search); ALA. Code tit. 15, § 153 (1959) (arrest w/warrant); ALA. Code tit. 15, § 155 (1959) (arrest w/o warrant); ALASKA CoMp. LAWS ANN. \$12.25.100 (1962) (arrest); Alaska Comp. Laws ANn. \&12.35.040 (1962) (search); ARIz. Rev. Stat. ANN. \$13-1411 (1956) (arrest); ArIz. Rev. Stat. ANN. \$13-1446 (1956) (search); ARK. Stat. Ann. \$ 43-414 (1947) (arrest); Cal. Pen. Code \$ 844 (arrest) ; Cal. Pen. CODE § 1531 (search); D.C. CODE ANN. \$25-129(g) (1961) (search liquor); D.C. Code AnN. §33-414(g) (1961) (search narcotics); Fla. Stat. AinN. \$901.19(1) (1944) (arrest) ; Fla. Stat. ANN. \$933.09 (1944) (search); GA. Code ANn. § $27-205$ (1953) (arrest w/warrant); GA. CoDE ANN. \$27-301 (1953) (search); HAwaII REV. LAws § 255-11 (1955) (arrest); HawaII REv. LAws § 255-22 (1955) (search); IDAHo Code ANN. § 19-611 (1947) (arrest); Idamo Code ANn. \$19-4409 (1947) (search) ; Ill. ANn. Stat. ch. 38, §695 (Smith-Hurd 1934) (search); Ind. ANN. STAT. \$9-1009 (1956) (arrest); IoWA CODE ANN. \$ 751.9 (1950) (search); IowA CODE ANa. \$ 755.9 (1950) (arrest); KAN. GEN. Stat. ANN. \$41-1007 (1949) (search liquor); Kan. Gen. Stat. Ann. \$ 62-1819 (1949) (arrest); Ky. Rev. Stat. ANN. \$70.077 (1962) (search questionable); Ky. Rev. Stat. Ann. \$70.078 (1962) (arrest w/warrant); KY. REv. STAT. ANN. $\$ 70.180$ (1962) (arrest w/o warrant questionable) ; La. Rev. Stat. ANN. \$15:46 (1950) (search); LA. Rev. Stat. ANN. \$15:72 (1950) (arrest) ; Mrch. Stat. Ann. \$28.880 (1954) (arrest) ; Mrnin. Stat. AnN. \$629.33 (1947) (arrest w/warrant); MnNN. Stat. ANn. \$629.34 (1947) (arrest w/o warrant); Miss. CoDE ANN. \$2471 (1956) (arrest) ; Mrss. Code ANN. $\$ 2614$ (1956) (search; liquor); Mo. ANN. Stat. \$544.200 (1953); Mont. Rev. Codes ANn. \$94-301-9 (1947) (search); Mont. Rev. Codes ANN. \$94-6011 (1947) (arrest); Neb. Rev. Stat. \$29-411 (1956) (arrest w/warrant; search) ; Nev. Rev. STAT. \$171.275 (1961) (arrest); NEv. REv. StaT. \$179.090 (1961) (search); N.Y. Code CrIm. Proc. \$ 175 (arrest w/warrant); N.Y. Code CrIM. Proc. \$ 178 (arrest w/o warrant); N.Y. CODE CrIM. Proc. \$799 (search) ; N.C. GeN. STAT. \$ 15-44 (1953) (arrest); N.D. Cent. Code \$29-06-14 (1960) (arrest); N.D. Cent. Code \$29-29-08 (1960) (search); OHIo Rev. Code ANN. \$2935.12 (Page Supp. 1962) (arrest; search); OKLA. STAT. ANN. tit. 22, \$194 (1937) (arrest w/warrant); Orla. Stat. ANN. tit. 22, $\$ 197$ (1937) (arrest w/o warrant); Orla. Stat. Ann. tit. 22, § 1228 (1958) (search) ; ORE. Rev. STAT. \$133.290 (1961) (arrest w/warrant); ORE. Rev. Stat. \$133.320 (1961) (arrest w/o warrant) ; ORE. Rev. Stat. \$ 141.110 (1961) (search) ; S.C. CoDE § 53-198 (1962) (arrest); S.D. CoDE § 34.1107 (1939) (search); S.D. Code \$34.1606 (1939) (arrest); TenN. Code ANn. \$ 40-509 (1955) (search); Tenn. Code AnN. \$ 40-807 (1955) (arrest); Tex. Code Crms. Proc. Ann. art. 242 (1954) (arrest); TEx. CODE CRIM. Proc. AlvN. art. 321 (1954) (search); UTAH Code ANn. \$ 77-13-12 (1953) (arrest); UTAm Code ANN. \$77-54-9 (1953) (search); WAsh. Rev. Code Ann. $\$ 10.31 .040$ (1961) (arrest); Wyo. Stat. Ann. \$7-165 (1957) (arrest w/warrant; search). 


\section{APPENDIX B}

\section{AN Act}

To amend chapter 205 of title 18, United States Code, with respect to announcement in the forcible execution of search warrants and making arrests; and other purposes.

Be it enacted by the Senate and House of Representatives of the United States of America in Congress assembled, That (a) section 3109 of title 18 of the United States Code is amended to read as follows:

“\$3109 Breaking doors or zeindozes for entry or exit to execute a search warrant or to make an arrest

"(a) Any officer authorized by law to make arrests, or to execute search warrants, or any person aiding such officer, may forcibly break and enter any outer or inner door, or window of a dwelling house, or other building, or any part thereof, or anything therein, or otherwise enter to execute a search or arrest warrant, or to make an arrest where authorized by law without a warrant, or where necessary to liberate himself or a person aiding him in the execution of such warrant, or in making such arrest.

"(b) Forcible breaking and entry shall not be made until after such person makes an announcement of identity and purpose, and admittance to the dwelling house is expressly or impliedly denied or unreasonably delayed.

"(c) An announcement shall not be required prior to such forcible breaking and entry where such person reasonably believes:

(1) his identity or purpose is already known to any person in the premises; or

(2) such notice would result in the destruction or concealment of evidence subject to seizure; or

(3) such notice would increase the possibility of bodily peril to such person or a third party; or

(4) such notice would permit the party to be arrested to escape; or

(5) such notice would otherwise be a useless gesture.

"(d) Evidence directly obtained because of a violation of this section, upon proper motion of a person aggrieved, shall not be admissible in evidence at any criminal hearing or trial. Evidence obtained after forcible or other entry by state officers made in conformity with state procedure without federal participation shall be admissible in any federal hearing or trial.

"(e) Whoever, after notice is given under subsection (b), or where the identity of the officer is already known, destroys, conceals, disposes of, or attempts to destroy, conceal or dispose of, or otherwise prevents, or attempts to prevent the seizure of, evidence subject to seizure shall be fined not more than $\$ 5,000$ or imprisoned not more than five years, or both.

"(f) As used in this Section:

(1) 'evidence subject to seizure' means any property for which a search warrant could be issued under Rule $41(\mathrm{~g})$ of the Federal Rules of Criminal Procedure, or which would be otherwise lawfully subject to seizure.

(2) 'forcibly break and enter' includes any use of physical force or violence but does not include entry obtained by trick or strategem unaccompanied by such force or violence.

(3) 'person aggrieved' means any person aggrieved within the meaning of Rule $41(\mathrm{e})$ of the Federal Rules of Criminal Procedure.

"(g) If any provision of this section, or the application of such provision to any person or circumstances, shall be held invalid, the remainder of this section or the application of such provision to persons or circumstances other than those as to which it is held invalid, shall not be affected thereby."

and (b) by deleting the present analysis to section 3109 in chapter 205 and adding the following item:

"Section 3109. Breaking doors or windows for entry or exit to execute a search warrant or to make an arrest." 